\title{
Das Human-Kapital: A Theory of the Demise of the Class Structure*
}

\author{
Oded Galor and Omer Moav ${ }^{\dagger}$
}

August 22, 2005

\begin{abstract}
This paper suggests that the demise of the capitalists-workers class structure was a socioeconomic transformation orchestrated by the capitalists in reaction to the increasing importance of the human capital of workers in sustaining their profit rates. Physical capital accumulation in the early stages of industrialization enhanced the importance of human capital in production and generated incentives for capitalists to support the provision of public education for the masses, planting the seeds for the demise of the existing class structure. The theory is supported by the voting patterns on England's education reform of 1902 .

Keywords: Industrial Revolution, Human Capital, Class Structure, Education Reforms
\end{abstract}

JEL Classification Numbers: B10, O10, O40

\footnotetext{
*The authors are grateful for comments from two anonymous referees, the Editor, Fabrizio Zilibotti, Daron Acemoglu, Josh Angrist, George Akerlof, Jordi Caballe, Edward Glaeser, Claudia Goldin, Herschel Grossman, Larry Katz, Victor Lavy, Joram Mayshar, Joel Mokyr, Daniele Paserman, Jim Robinson, David Weil and seminar participants at the NBER Summer Institute, the Euroconference on Innovation, Economic Growth, Barcelona, DIGIT, Vienna, 2001, CEPR Conference, Copenhagen, 2001, AEA, 2002, and CEPR Conference, Paris, 2003. Paula Green, Daniel Meija, Ruti Polachek, Tamar Roth, Analia Schlosser, and Dietrich Vollrath provided excellent research assistance. The Authors' research was supported by the ISF. Galor's research is supported by NSF Grant SES-0004304.

${ }^{\dagger}$ Galor: Department of Economics, Brown University, Providence RI 02912, USA, and Department of Economics, Hebrew University, Jerusalem 91905, Israel; e-mail Oded_Galor@brown.edu. Moav: Hebrew University, Shalem Center, and CEPR; e-mail: msmoav@huji.ac.il
} 
"The history of society is the history of struggles between social classes"

Karl Marx

\section{Introduction}

This paper suggests that a significant driving force in the demise of the European capitalistsworkers class structure was a socio-economic transformation orchestrated by the capitalists in reaction to the increasing importance of the human capital of workers in sustaining their profit rates. The accumulation of physical capital in the early stages of industrialization enhanced the importance of human capital in the production process and generated an incentive for the capitalists to support the provision of public education for the masses, planting the seeds for the demise of the existing class structure.

Existing theories about the demise of the capitalists-workers class structure focus on the role of a class struggle in this significant change. According to the Marxist theory, capital accumulation and the associated decline in profit rates would intensify the degree of exploitation of workers and would bring about a class struggle between workers and capitalists that would eventually terminate the existing class society. The recent political economy literature, discussed in the next section, accepts the basic Marxist premise regarding the significant role of the rising tension between workers and capitalists in the changes of the class structure. It suggests, however, that social and political reforms in Western Europe during the 19th century were an outcome of deliberate concessions by the elite designed to avert political instability, expropriation, and possibly a revolution.

In contrast to this viewpoint, we argue that a significant force in the demise of the class structure was a by-product of a productive cooperation between capitalists and workers. According to the theory, in the early stages of industrialization, when physical capital was the prime engine of economic growth, societies were marked by a stable class structure characterized by a dichotomous ownership on factors of production. Due to capital-skill complementarity, the accumulation of physical capital by the capitalists increased the importance of human capital in sustaining the rate of return to physical capital and brought about a non-altruistic change in the attitude of capitalists towards the provision of public education for the masses. ${ }^{1}$ The capitalists found it beneficial to support universal publicly financed education, enhancing the participation of the working class in the process of human and physical capital accumulation, leading to a widening of the middle class and to the eventual demise of the capitalists-workers class structure. ${ }^{2}$ Thus, we argue that

\footnotetext{
${ }^{1}$ Since firms have limited incentive to invest in the general human capital of their workers, in the presence of credit market imperfections, the level of education would be suboptimal unless it would be financed publicly.

${ }^{2}$ Indeed, the second phase of the Industrial Revolution was associated with a widening middle class of white-collar workers, skilled artisans, and independent entrepreneurs (Cameron (1989, p. 213)). Moreover, the development of the middle class was encouraged by industrialists who demanded not only a more educated labor force but an
} 
Karl Marx's highly influential prediction about the inevitable class struggle due to declining profit rates stemmed from an under-appreciation of the role that human capital eventually played in the production process.

The theory is based on three central elements. First, the production process is characterized by capital-skill complementarity. ${ }^{3}$ Capitalists therefore benefit from the aggregate accumulation of human capital in society. Second, human capital is inherently embodied in individuals and its accumulation is characterized by decreasing marginal returns at the individual level. The aggregate stock of human capital, is therefore, larger if its accumulation is widely spread among individuals in society. Capitalists therefore gain from a universal provision of education. Third, in the absence of public education, investment in human capital is suboptimal due to borrowing constraints. Public education therefore enhances investment in human capital by the masses, and may therefore benefit the capitalists as well as the workers. ${ }^{4}$

The theory suggests that the utilitarian support of capitalists for the provision of universal public education was instrumental for the rapid formation of human capital and was therefore a catalyst, and possibly even a necessary condition, for the demise of the class society. The support for public education is unanimous among workers and capitalists who carry its prime financial burden. ${ }^{5}$ That is, due to the coexistence of credit market imperfections and capital-skill complementarity, the redistribution associated with public education is Pareto improving. ${ }^{6}$

The willingness of the capitalists to support universal public education rather than selective industrial education captures two of the underlying forces in the complementarity between human capital and physical capital. First, it appears that in the second phase of the Industrial Revolution the increase in basic literacy that was associated with universal primary education raised labor productivity. Second, investment in universal primary education generated a wider talent pool for intermediate class of people who could serve in managerial and marketing positions (Anderson (1975, p.193)).

${ }^{3}$ See Goldin and Katz (1998) for evidence regarding capital-skill complementarity.

${ }^{4}$ See Galor and Zeira (1993), Benabou (1996), Durlauf (1996), and Galor and Moav (2004) for the effect of credit market imperfections on investment in human capital and economic growth in an unequal society. In particular, Galor and Moav (2004) offer a unified account for the effect of income inequality on the process of development. They argue that the replacement of physical capital accumulation by human capital accumulation as a prime engine of economic growth changed the qualitative impact of inequality on the process of development. In the absence of an effective cooperation in the provision of public schooling, equality alleviates the adverse effect of credit constraints and promotes human capital accumulation and economic growth.

${ }^{5}$ The distribution of the cost of education between workers and capitalists may differ across countries due to differences in their socio-political structure as well as their stage of development. Nevertheless, regardless of the distribution of political power in society, in light of the importance of nourishment and health for human capital formation and labor supply, capitalists are unlikely to impose the prime financial burden on the working class as long as wages do not significantly exceed the subsistence level of consumption.

${ }^{6}$ This result is related to Benabou (2000), who demonstrates that when capital and insurance markets are imperfect, policies which redistribute wealth from richer to poorer individuals can have a positive net effect on aggregate output and growth. Unlike the current study in which the support for growth-enhancing redistribution via public education is unanimous, in Benabou (2000) redistributions are only supported by a wide consensus in a fairly homogeneous society but face strong opposition in an unequal one. See Benabou (2002) as well. 
advanced industrial and managerial occupations, benefiting the production process at the higher end.

Our thesis implies that a conflict of interest would emerge between owners of factors of production that differ in their degree of complementary with human capital. In particular, the theory suggests that a conflict of interest about the timing of the implementation of growth enhancing educational policies would emerge primarily among the economic elites - industrialists and landowners - rather than between the ruling elite and the masses. ${ }^{7}$

Historical evidence presented in Section 3 suggests that, consistent with the proposed theory, the process of industrialization enhanced the importance of human capital in production and induced the capitalists to lobby for the provision of universal public education. Furthermore, as suggested by the theory, the acquisition of human capital by the working class in the second phase of the Industrial Revolution and the associated increase in wages, in particular relative to the return to capital, brought about a gradual demise of the capitalist-workers class distinction.

The basic premise of this research, regarding the positive attitude of the capitalists towards education reforms, is examined based on the voting patterns on the Balfour Act of 1902 - the proposed education reform in the UK that marked the consolidation of a national education system and the creation of a publicly supported secondary school system. Variations in the support of MPs for the Balfour Act would reflect the variations in the skill intensity in the counties they represent. Higher support for the Balfour Act would be expected from MPs who represent industrial skillintensive counties. The empirical analysis supports the main hypothesis. It establishes that there exists a significant positive effect of skill-intensiveness of the industrial sector in a county on the propensity of the MPs to vote in favor of the education reform proposed by the Balfour Act of 1902.

\section{Related Literature}

The effect of social conflict on political and educational reforms was examined by Bowles and Gintis (1975), Grossman (1994), Grossman and Kim (1999), Acemoglu and Robinson (2000), Bourguignon and Verdier (2000), and Bertocchi and Spagat (2004), among others. They argue that reforms and redistribution from the elite to the masses diminish the tendency for socio-political instability and predation, and may therefore stimulate investment and economic growth. In particular, several studies examine the potential benefits for the elite from educational reforms. Bourguignon and

\footnotetext{
${ }^{7}$ Galor, Moav and Vollrath (2003) examine the effect of a conflict of interest between capitalists and landowners on education reforms. They establish theoretically and empirically the existence of a negative effect of land inequality on public expenditure on education. Their findings support the thesis of this paper, demonstrating that even in the presence of a class of landowners, cooperation between workers and capitalists, in the context of education reforms, may emerge.
} 
Verdier (2000) suggest that if political participation is determined by the education (socioeconomic status) of citizens, the elite may not find it beneficial to subsidize universal public education despite the existence of positive externalities from human capital. Grossman and Kim (1999) argue that education decreases predation, and Bowles and Gintis (1975) suggest that educational reforms are designed to sustain the existing social order, by displacing social problems into the school system.

In contrast, we argue that a significant force in the demise of the class structure was a by-product of a productive cooperation between capitalists and workers, rather than an outcome of a divisive class struggle. Mutually beneficial reforms are also considered by Lizzeri and Persico (2004) and Doepke and Zilibotti (2005). Lizzeri and Persico (2004) argue that provision of public services may have served the interest of the elite as well as masses, and therefore the extension of franchise redirects resources from wasteful redistribution to public goods. Doepke and Zilibotti (2005) argue that child labor regulation may benefit capitalists by inducing parents to educate their children, increasing the average skill of the work force. Although they place emphasize on the political preference of the working class, since historically unions rather than factory owners were the main active campaigners for child labor regulation, the success of the unions' action may have been possible only because of diminished opposition from industrialists.

\section{Historical Evidence}

Historical evidence suggests that, consistent with the proposed theory, a significant driving force in the demise of the capitalists-workers class structure was the eagerness of the capitalists to invest in the education of workers in reaction to the increasing importance of human capital in sustaining their profit rates. In particular, Section 3.1 presents evidence that the process of industrialization enhanced the importance of human capital in production and induced the capitalists to lobby for the provision of universal public education. Section 3.2 provides evidence demonstrating that the accumulation of human capital by the working class in the second phase of the Industrial Revolution was associated with an increase in wages, in particular relative to the return to capital, in line with a fading capitalists-workers class distinction. Finally, Section 3.3 presents evidence that dispels an alternative hypothesis that political reforms during the 19th century shifted the balance of power towards the working class and enabled workers to implement education reforms against the will of the capitalists.

\subsection{Industrial Development and Education Reforms}

Evidence suggests that the experience of the Western World throughout the various phases of the Industrial Revolution is consistent with the hypothesis of this research about the link between industrial development and educational reforms. The process of industrialization was character- 
ized by a gradual increase in the relative importance of human capital for the production process (Abramovitz 1993). In the first phase of the Industrial Revolution, human capital had a limited role in the production process. Education was motivated by a variety of reasons, such as religion, social control, moral conformity, socio-political stability, social and national cohesion, military efficiency, and the Age of Enlightenment. The extensiveness of public education was therefore not necessarily correlated with industrial development and it differed across countries due to political, cultural, social, historical and institutional factors. ${ }^{8}$ In the second phase of the Industrial Revolution, education reforms were designed primarily to satisfy the increasing skill requirements in the process of industrialization, reflecting the interest of capitalists in human capital formation and thus in the provision of public education. ${ }^{9}$ The evidence suggests that in Western Europe, the economic interests of capitalists were indeed a significant driving force behind the implementation of educational reforms. ${ }^{10}$

\subsubsection{England}

In the first phase of the Industrial Revolution (1760-1830), consistent with the proposed hypothesis, capital accumulation increased significantly without a corresponding increase in the supply of skilled labor. ${ }^{11}$ In contrast, literacy rates evolved rather slowly and the state devoted virtually no resources to raising the level of literacy of the masses. ${ }^{12}$ During the first stages of the Industrial Revolution, literacy was largely a cultural skill or a hierarchical symbol and had limited demand in the production process (Mitch (1992), and Mokyr (1993, 2001)). For instance, in 1841 only 4.9\% of male workers and only $2.2 \%$ of female workers were in occupations in which literacy was strictly required (Mitch (1992, pp. 14-15)). During this period, an illiterate labor force could operate the existing technology, and economic growth was not impeded by educational retardation. ${ }^{13}$ Workers developed skills primarily through on-the-job training, and child labor was highly valuable (Kirby 2003).

The development of a national public system of education in England lagged behind that of

\footnotetext{
${ }^{8}$ For instance, Sandberg (1979) argues that the level of human capital in Sweden prior to 1850 was larger than the level that would have been justified by its stage of development.

${ }^{9}$ The form of human capital that was complementary to physical capital was rather broad, including literacy, quantitative abilities, and general knowledge, as well as work habits, such as punctuality, discipline, manners, and diligence (Graff 1987).

${ }^{10}$ One could argue that the rise in income during the second phase of the industrial revolution brought about an increase in education since people view education as a normal consumption good. The evidence that we provide in this section clarifies that the mechanism that we underlined is a significant force behind the accumulation of human capital during this period.

${ }^{11}$ For instance, the investment ratio increased from $6 \%$ in 1760 to $11.7 \%$ in the year 1831 (Crafts (1985, p. 73$)$ ).

${ }^{12}$ Cipolla (1969), Stone (1969), and Schofield (1973), and Cressy (1980) show that literacy rates have increased during the first phase of the industrial revolution but at a slower rate than in the second phase.

${ }^{13}$ Some have argued that the low skill requirements even declined over this period. For instance, Sanderson (1995, p. 89) suggests that "One thus finds the interesting situation of an emerging economy creating a whole range of new occupations which require even less literacy and education than the old ones."
} 
the continental countries by nearly half a century (Sanderson (1995, pp. 2-10)). ${ }^{14}$ Britain's early industrialization occurred without a direct state intervention in the development of the minimal skills that were required in production (Green (1990, pp. 293-294)). Furthermore, as argued by Landes (1969, p. 340) "although certain workers - supervisory and office personnel in particular - must be able to read and do the elementary arithmetical operations in order to perform their duties, large share of the work of industry can be performed by illiterates as indeed it was especially in the early days of the industrial revolution."

England initiated a sequence of reforms in its education system since the 1830s and literacy rates gradually increased. The process was initially motivated by a variety of reasons such as religion, enlightenment, social control, moral conformity, socio-political stability, and military efficiency, as was the case in other European countries (e.g., Germany, France, Holland, Switzerland) that had supported public education much earlier. ${ }^{15}$ However, in light of the modest demand for skills and literacy by the capitalists, the level of governmental support was rather small. ${ }^{16}$

In the second phase of the Industrial Revolution, consistent with the proposed hypothesis, the demand for skilled labor in the growing industrial sector markedly increased (Cipolla 1969 and Kirby 2003) and the proportion of children aged 5 to 14 in primary schools increased from $11 \%$ in 1855 to $25 \%$ in 1870 (Flora et al. (1983)). ${ }^{17}$ In light of the industrial competition from other countries, capitalists started to recognize the importance of technical education for the provision of skilled workers. As noted by Sanderson (1995, pp. 10-13), "reading ...enabled the efficient functioning of an urban industrial society laced with letter writing, drawing up wills, apprenticeship indentures, passing bills of exchange, and notice and advertisement reading." Manufacturers argued that: "universal education is required in order to select, from the mass of the workers, those who respond well to schooling and would make a good foreman on the shop floor" (Simon (1987, p. 104)). Furthermore, in 1824, Alexander Galloway, the master-engineer, reported: "I have found from the mode of managing my business, by drawings and written descriptions, a man is not of much use to me unless he can read and write. If a man applies for work, and says he cannot read

\footnotetext{
${ }^{14}$ For instance, in his parliamentary speech in defense of his 1837 education bill, the Whig politician, Henry Brougham, reflected upon this gap: "It cannot be doubted that some legislative effort must at length be made to remove from this country the opprobrium of having done less for education of the people than any of the more civilized nations on earth" (Green (1990, pp.10-11)).

${ }^{15}$ Wiener (1981), as well as others, argued in contrast, that the educational system in Britain was initially designed to accentuate and perpetuate class differences, however, with "little attention or status to industrial pursuits" (p. 24). This pre-existing motivation for education had therefore a limited effect on the relative earnings of the elite and is thus tangential to the hypothesis derived in this paper. Thus, although the aspects of education that were designed to accentuate class differences may have affected the social characteristics of the elite and the masses, they have not counterbalanced the trend towards the gradual participation of the decedents of the working class in the accumulation of physical and human capital.

${ }^{16}$ Even in 1869 the government funded only one-third of school expenditure (Green, 1990, pp. 6-7).

${ }^{17} \mathrm{Job}$ advertisements, for instance, suggest that literacy became an increasingly desired characteristic for employment as of the 1850s (Mitch (1993, p. 292)).
} 
and write, he is asked no more questions." (Thompson, 1968).

As it became apparent that skills were necessary for the creation of an industrial society, capitalists had an increasing interest in the level of education of the masses. ${ }^{18}$ Initially the capitalists established the factory schools in order to educate the children they employed. The Factory Acts of 1802 and 1833 made it mandatory for some manufacturers to set up such schools. These laws were poorly enforced and the factory schools were not widespread, nor were they well received. (Cameron (1989, p. 216-217), Cipolla (1969, p. 66-69), Smelser (1991)). The pure laissezfaire policy failed in developing a proper educational system and capitalists demanded government intervention in the provision of education. As James Kitson, a Leeds iron-master and advocate of technical education explained to the Select Committee on Scientific Instruction (1867-1868): "... the question is so extensive that individual manufacturers are not able to grapple with it, and if they went to immense trouble to establish schools they would be doing it in order that others may reap the benefit" (Green, 1990, p. 295).

An additional turning point in the attitude of capitalists towards public education was the Paris Exhibition of 1867, where the limitations of English scientific and technical education became clearly evident. Unlike the 1851 exhibition in which England won most of the prizes, the English performance in Paris was rather poor; of the 90 classes of manufacturers, Britain dominated only in 10. Lyon Playfair, who was one of the jurors, reported that: "a singular accordance of opinion prevailed that our country has shown little inventiveness and made little progress in the peaceful arts of industry since 1862." This lack of progress "upon which there was most unanimity conviction is that France, Prussia, Austria, Belgium and Switzerland possess good systems of industrial education and that England possesses none" (Green (1990, p. 296)).

The government established various parliamentary investigations into the relationship between science, industry, and education, that, according to the proposed theory, were designed to address the capitalists' outcry about the necessity of universal public education. A sequence of reports by these committees in the years 1868-1882, underlined the inadequate training for supervisors, managers and proprietors, as well as workers (Green (1990, pp. 297-298)). In particular, W. E. Forster, the Vice President of the committee of the Council of Education told The House of Commons: "Upon the speedy provision of elementary education depends our industrial prosperity...if we leave our work-folk any longer unskilled...they will become overmatched in the competition of the world" (Hurt (1971, pp. 223-224)). They proposed to organize a state inspection of elementary and secondary schools and to provide efficient education geared towards the specific needs of its consumers. In particular, The Royal Commission on Technical Education of

\footnotetext{
${ }^{18}$ As hypothesized in this paper, there was a growing consensus among workers and capitalists about the virtues of reform. The labor union movement was increasingly calling for a national system of non-sectarian education (Green, 1990, p. 302).
} 
1882 confirmed that England was being overtaken by the industrial superiority of Prussia, France and the United States and recommended the introduction of technical and scientific education into secondary schools.

As argued in the proposed theory, it appears that the government gradually yielded to the pressure by capitalists and increased its contributions to elementary as well as higher education. In the 1870 Education Act, (prior to the significant extension of the franchise of 1884 that made the working class the majority in most industrial counties), the government assumed responsibility for ensuring universal elementary education, although it did not provide either free or compulsory education at the elementary level. (Green, (1990, p. 299)). School enrollment of 10-year-olds increased from $40 \%$ in 1870 to $100 \%$ in 1900, the literacy rate among men, increased from $65 \%$ in the first phase of the Industrial Revolution, to nearly $100 \%$ at the end of the 19th century (Clark (2002)), and the proportion of children aged 5 to 14 in primary schools increased significantly in the second half of the 19th century, from $11 \%$ in 1855 to $74 \%$ in 1900 (Flora et al. (1983)). Finally, the 1902 Balfour Act marked the consolidation of a national education system and created state secondary schools (Ringer (1979)). Furthermore, science and its application in technology gained prominence (Mokyr (1990, 2002)). New universities were established with a strong emphasis on professional training in the medical, legal, engineering and economic studies (Sanderson (1995, p. 47)).

\subsubsection{Continental Europe}

The early development of public education occurred in the western countries of continental Europe (e.g., Prussia, France, Sweden, and the Netherlands) well before the Industrial Revolution. The process was motivated by a variety of reasons, such as religion, enlightenment, social control, moral conformity, socio-political stability, social and national cohesion, and military efficiency (Scott (1977), Graff (1987)). As was the case in England, massive educational reforms occurred in the second half of the 19th century due to the rising demand for skills in the process of industrialization (Cipolla 1969). Technical and scientific education had been vigorously promoted as an essential element of competitiveness and economic growth (Green (1990, pp. 293-294)).

In France, indeed, the initial development of the education system occurred well before the Industrial Revolution, but the process was intensified and transformed to satisfy industrial needs in the second phase of the Industrial Revolution. The early development of elementary and secondary education in the 17 th and 18 th centuries was dominated by the church and religious orders. Some state intervention in technical and vocational training was designed to reinforce development in commerce, manufacturing and military efficiency. After the French Revolution, the state established universal primary schools. Nevertheless, enrolment rates remained rather low. The state 
concentrated on the development of secondary and higher education with the objective of producing an effective elite to operate the military and governmental apparatus. Secondary education remained highly selective, offering general and technical instruction largely to the middle class (Green (1990, pp. 135-137 and 141-142)). Legislative proposals during the National Convention quoted by Cubberley (1920, pp. 514-517) are revealing about the underlying motives for education in this period: “... Children of all classes were to receive that first education, physical, moral and intellectual, the best adapted to develop in them republican manners, patriotism, and the love of labor... They are to be taken into the fields and workshops where they may see agricultural and mechanical operations going on..."

The process of industrialization in France and the associated increase in the demand for skilled labor, as well as the breakdown of the traditional apprenticeship system, significantly affected the attitude towards education. State grants for primary schools were gradually increased in the 1830s and legislation made an attempt to provide primary education in all regions, extend the higher education, and provide teacher training and school inspections. The number of communities without schools fell by $50 \%$ from 1837 to 1850 and as the influence of industrialists on the structure of education intensified, education became more stratified according to occupational patterns (Anderson $(1975$ p. 15, 31)). The eagerness of capitalists for rapid education reforms was reflected by the organization of industrial societies that financed schools specializing in chemistry, design, mechanical weaving, spinning, and commerce (Anderson (1975, p 86, 204)).

As was the case in England, industrial competition led industrialists to lobby for the provision of public education. The Great Exhibition of 1851 and the London Exhibition of 1862 created the impression that the technological gap between France and other European nations was narrowing and that French manufacturers ought to invest in the education of their labor force to maintain their technological superiority. Subsequently, the reports on industrial education by commissions established in the years 1862 to 1865 reflected the plea of industrialists for the provision of industrial education on a large scale and for the implementation of scientific knowledge in the industry. "The goal of modern education... can no longer be to form men of letters, idle admirers of the past, but men of science, builders of the present, initiators of the future." ${ }^{19}$ (Anderson (1975, p. 194)). Education reforms in France were extensive in the second phase of the Industrial Revolution, and by 1881 a universal, free, compulsory and secular primary school system had been established and technical and scientific education further emphasized. Illiteracy rates among conscripts tested at the age of 20 declined gradually from $38 \%$ in 1851-55 to $17 \%$ in 1876-80 (Anderson (1975, p. 158)), and the proportion of children aged 5 to 14 in primary schools increased from $51 \%$ in 1850 to $86 \%$ in 1901 (Flora et al. (1983)).

\footnotetext{
${ }^{19}$ L'Enseignement professionnel, ii (1864), p. 332, quoted in Anderson (1975).
} 
In Prussia, as well, the initial steps towards compulsory education took place at the beginning of the 18th century well before the Industrial Revolution. Education was viewed at this stage primarily as a method to unify the state (Schleunes 1989 and Tipton 2003). In the second part of the 18th century, education was made compulsory for all children aged 5 to 13 . Nevertheless, these regulations were not strictly enforced due to the lack of funding associated with the difficulty of taxing landlords for this purpose, and due to the loss of income from child labor. ${ }^{20}$ At the beginning of the 19th century, motivated by the need for national cohesion, military efficiency, and trained bureaucrats, the education system was further reformed, making education a secular activity and compulsory for a three-year period, and reconstituting the Gymnasium as a state institution providing nine years of education for the elite (Cubberly (1920)).

The process of industrialization in Prussia and the associated increase in the demand for skilled labor led to significant pressure for educational reforms and thereby to the implementation of universal elementary schooling (Green 1990). Taxes were imposed to finance the school system and teachers' training and certification were established. Secondary schools started to serve industrial needs as well. The Realschulen, which emphasized the teaching of mathematics and science, was gradually adopted, and vocational and trade schools were founded. Total enrolment in secondary school increased six fold from 1870 to 1911 (Flora et al. (1983)). "School courses...had the function of converting the occupational requirements of public administration, commerce and industry into educational qualifications..." (Muller (1987, pp. 23-24)). Furthermore, the Industrial Revolution significantly affected the nature of education in German universities. German industrialists who perceived advanced technology as the competitive edge that could boost German industry, lobbied for reforms in the operation of universities, and offered to pay to reshape their activities so as to favor their interest in technological training and industrial applications of basic research (McClelland (1980, p. 300-301)).

Similarly, the structure of education in the Netherlands and Belgium reflected the interest of capitalists in the skill formation of the masses. In the Netherlands, as early as the 1830s, industrial schools were established and funded by private organizations, representing industrialists and entrepreneurs. Ultimately, in the latter part of the 19th century, the state, urged by industrialists and entrepreneurs, started to support these schools (Wolthuis (1999, pp. 92-93, 119, 139-140, 168, 171-172)). In Belgium, primary education was backward in comparison with other European countries and a compulsory education system was established only at the beginning of the 20th century, when illiteracy rate was $19 \%$. Nevertheless, industrial development prompted the establishment of the industrial school as of 1818 , financed by local industrialists. These schools expanded rapidly

\footnotetext{
${ }^{20}$ Indicative of the realization by the elite that education was more significant for the urban production process is the statement by Frederick II in 1979 about education: "...if they learn too much they will run off to the cities to become secretaries or some such things." (Schleunes 1989).
} 
in the midst of the 19th century (Mallinson (1963)).

\subsubsection{United States}

The process of industrialization in the US also increased the importance of human capital in the production process. Evidence provided by Abramowitz and David (2000) and Goldin and Katz (2001) suggests that over the period 1890-1999, the contribution of human capital accumulation to the growth process of the United States nearly doubled. ${ }^{21}$ As argued by Goldin (1999), the rise of the industrial, business and commerce sectors in the late 19th and early 20th centuries increased the demand for managers, clerical workers, and educated sales personnel who were trained in accounting, typing, shorthand, algebra, and commerce. Furthermore, in the late 1910s, technologically advanced industries demanded blue-collar craft workers who were trained in geometry, algebra, chemistry, mechanical drawing, etc. The structure of education was transformed in response to industrial development and the increasing importance of human capital in the production process, and high schools adapted to the needs of the modern workplace of the early 20th century. Total enrolment in public secondary schools increased 70-fold from 1870 to 1950 (Kurian 1994).

Nevertheless, due to differences in the structure of education finance in the US in comparison to European countries, capitalists in the US had only limited incentives to lobby for the provision of education and support it financially. Unlike the central role that government funding played in the provision of public education in European countries, the evolution of the education system in the US was based on local initiatives and funding. The local nature of the education initiatives in the US induced community members, in urban as well as rural areas, to play a significant role in advancing their schooling system. Capitalists, however, faced limited incentives to support the provision of education within a county in an environment where labor was mobile across counties and the benefits from educational expenditure in one county may be reaped by employers in other counties.

\subsection{Schooling, Factor Prices and Inequality}

The main hypothesis of this research suggests that in the first phase of the Industrial Revolution, prior to the implementation of significant education reforms, physical capital accumulation was the prime engine of economic growth and the concentration of capital among the capitalist class widened wealth inequality. Once education reforms were implemented, however, the significant increase in the return to labor relative to capital, as well as the significant increase in the real

\footnotetext{
${ }^{21}$ It should be noted that literacy rates in the US were rather high prior to this increase in the demand for skilled labor. Literacy rates among the white population were already $89 \%$ in $1870,92 \%$ in 1890 , and $95 \%$ in 1910 (Engerman and Sokoloff (2000)). Education in earlier periods was motivated by social control, moral conformity, and social and national cohesion, as well as required skills for trade and commerce.
} 
return to labor and the associated accumulation of assets by the workers, brought about a decline in inequality and eventually the demise of the European 19th century class structure. ${ }^{22}$

The theory predicts that in the first phase of the Industrial Revolution, prior to the implementation of education reforms, capital accumulation brought about a gradual increase in wages along with an increase in the wage-rental ratio. Education reforms in the second phase of the Industrial Revolution are expected to generate a sharp increase in real wages along with a sharp increase in the wage-rental ratio. Finally, wealth inequality is predicted to widen in the first phase of the Industrial Revolution and to reverse its course in the second phase, once significant education reforms have been implemented.

Indeed, evidence from the UK supports this hypothesis. As depicted in Figures 1(c) and $1(d)$, based on the data set of Clark $(2002,2003)$, real wages as well as the wage-rental ratio increase dramatically from 1870 well into the 20 th century. ${ }^{23}$ These changes in factor prices reflect the increase in enrolment rates, as depicted in Figure 1(a) (in particular the process of education reforms from 1830 to 1870 and its consolidation in the Education Act of 1870) and its delayed effect on the skill level per worker. ${ }^{24}$ Thus, it appears that the demise of the class structure is indeed associated with the significant changes that occurred around 1870 in the relative returns to the main factors of production possessed by capitalists and workers. ${ }^{25}$ As documented in the controversial study by Williamson (1985) about the evolution of inequality in the time period 1823-1915, wealth inequality in the UK reached a peak around 1870 and declined thereafter (Figure 1(b)), in close association with the patterns of enrolment rates and factor prices. ${ }^{26}$

Similar patterns of the effect of education on factor prices and therefore on inequality are

\footnotetext{
${ }^{22}$ The rise in inequality in mature stages of development due to skilled or ability-biased technological change (e.g., Katz and Murphy (1992), Galor and Tsiddon (1997), Acemoglu (1998), Caselli (1999), and Galor and Moav (2000)) does not reflect a reversal in the demise of the class structure. It is not related to class association as reflected partly by increased intergenerational mobility (e.g., Galor and Tsiddon (1997), Maoz and Moav (1999), Hassler and Rodriguez-Mora (2000)).

${ }^{23}$ Clark (2003) constructs three series for wages in England over this period. Farm wage, Helper Wage, and Craftsmen Wage. Figures 1(c) and 1(d) are based on Helper wage. (Craftsmen wage generate similar time path). Farm wage appears less relevant given the focus of the paper. Moreover, it should be noted that the return to capital increased moderately over this period, despite the increase in the supply of capital, reflecting technological progress, population growth, and accumulation of human capital.

${ }^{24}$ It should be noted that although the demand for skill labor increased in the process, the skill premium is rather stable over this period (Clark 2003). The lack of clear evidence about the increase in the return to human capital over this period is not an indication for the absence of a significant increase in the demand for human capital. However, the significant increase in schooling that took place in the 19th century, and in particular the introduction of public education that lowered the cost of education, generated a significant increase in the supply of educated workers and operated towards a reduction in the return to human capital.

${ }^{25}$ Throughout the period 1873-1913 in which real wages increase significantly, the growth rate of output per capita is explained entirely by the contributions of physical and human capital accumulation. Thus, TFP growth is zero over this period, depicting a marked decline over a $0.6 \%$ annual TFP growth in the period 1856-1873. (Mattews et al. (1982)). An increase in labor-augmenting technological change is therefore not a viable explanation for relative and absolute increases in real wages and the decline in inequality in the UK over this period.

${ }^{26}$ Feinstien (1988), criticizes Williamson's methodology of data construction, but does not provide an alternative that refutes the hump shape evolution of inequality over this period.
} 
observed in France as well. As argued by Morrisson and Snyder (2000), wealth inequality in France increased during the first half of the 19th century, and as depicted in Figure 2(b), started to decline in the last decades of the 19th century in close association with the patterns of enrolment rates and factor prices, depicted in Figures 2(a), 2(c) and 2(d). The decline in inequality in France appears to be associated with the significant changes in the relative returns to the main factors of production possessed by capitalists and workers in the second part of the 19th century. As depicted in Figures 2(c) and 2(d), based on the data presented in Levy-Leboyer and Bourguignon (1990), real wages as well as the wage-rental ratio increase significantly as of 1860, reflecting the effect of the increase in enrolment rates on the skill level per worker.

The German experience is consistent with this pattern as well. Inequality in Germany started to decline towards the end of the 19th century (Morrisson and Snyder (2000)) in association with a significant increase in the real wages and in the wage-rental ratio from the 1880s (Spree (1977) and Berghahn (1994)), which is in turn related to the provision of industrial education in the second half of the 19th century.

The link between the expansion of education and the reduction in inequality is present in the US as well. Wealth inequality in the US, which increased gradually from colonial times until the second half of the 19th century, reversed its course at the turn of the century and maintained its declining pattern during the first half of the 20th century (Lindert and Williamson (1976)). As argued by Goldin (2001), the emergence of the "new economy" in the early 20th century increased the demand for educated workers. The creation of publicly funded mass modern secondary schools from 1910 to 1940 provided general and practical education, contributed to workers productivity and opened the gates for college education. This expansion facilitated social and geographic mobility and generated a large decrease in inequality in economic outcomes.

\subsection{The Timing of Educational and Political Reforms}

This research suggests that education reforms were initiated by the capitalists in reaction to the increasing importance of human capital in sustaining their profit rates. An alternative hypothesis may be that political reforms during the 19th century shifted the balance of power towards the working class, and enabled workers to implement education reforms against the will of the elite. ${ }^{27}$ The evidence, however, does not support this alternative hypothesis.

Education reforms took place in autocratic states that did not relinquish political power throughout the 19th century, and major reforms occurred in societies in the midst of the process of democratization well before the stage at which the working class constituted the majority among

\footnotetext{
${ }^{27}$ See for instance, Acemoglu and Robinson (2000), where the extension of the franchise during the 19th century is viewed as a commitment devise to ensure future income redistribution from the elite to the masses.
} 
the voters. In particular, the most significant education reforms in the UK were completed before the voting majority shifted to the working class. The patterns of education and political reforms in the UK during the 19th century are depicted in Figure 3(a). The Reform Act of 1832 nearly doubled the total electorate, but nevertheless only $13 \%$ of the voting-age population was enfranchised. The artisans, the working classes, and some sections of the lower middle classes remained outside of the political system. The franchise was extended further in the Reform Acts of 1867 and 1884 and the total electorate nearly doubled in each of these episodes. However, working-class voters did not become the majority in all urban counties until 1884 (Craig (1989)).

The onset of England's education reforms, and in particular, the fundamental Education Act of 1870 and its major extension in 1880 occurred prior to the political reforms of 1884 that made the working class the majority in most counties. As depicted in Figure 3(a), a trend of significant increase in primary education was established well before the extension of the franchise in the context of the 1867 and 1884 Reform Acts. In particular, the proportion of children aged 5 to 14 in primary schools increased five-fold (and surpassed 50\%) over the three decades prior to the qualitative extension of the franchise in 1884 in which the working class was granted a majority in all urban counties. Furthermore, the political reforms do not appear to have any effect on the pattern of education reform. In fact, the average growth rate of education attendance from decade to decade over the period 1855 to 1920 reaches a peak at around the Reform Act of 1884 and starts declining thereafter. ${ }^{28}$

Similar pattern occurred in other European countries. In France the expanding pattern of education preceded the major political reform that gave the voting majority to the working class. The patterns of education and political reforms in France during the 19th century are depicted in Figure 3(b). Prior to 1848, restrictions limited the electorate to less than $2.5 \%$ of the voting-age population. The 1848 revolution led to the introduction of nearly universal voting rights for males. Nevertheless, the proportion of children aged 5 to 14 in primary schools doubled (and exceeded $50 \%$ ) over the two decades prior to the qualitative extension of the franchise in 1848 in which the working class was granted a majority among voters. Furthermore, the political reforms of 1848 do not appear to have any effect on the pattern of education expansion. Political reforms in the Netherlands did not affect the trend of education expansion and the proportion of children aged 5 to 14 in primary schools exceeded $60 \%$ well before the major political reforms of 1887 and 1897 . Similarly, the trends of political and education reforms in Sweden, Italy, Norway, Prussia and Russia do not lend credence to the alternative hypothesis.

\footnotetext{
${ }^{28} \mathrm{It}$ is interesting to note, however, that the abolishment of education fees in nearly all elementary schools occurs only in 1891, after the Reform Act of 1884, suggesting that the political power of the working class may have affected the distribution of education cost across the population, but consistent with the proposed thesis, the decision to educate the masses was taken independently of the political power of the working class.
} 


\section{The Basic Structure of the Model}

Consider a closed overlapping-generations economy in a process of development. In every period the economy produces a single homogeneous good that can be used for consumption and investment. The good is produced using physical capital and human capital. Output per-capita grows over time due to the accumulation of these factors of production. ${ }^{29}$ The stock of physical capital in every period is the output produced in the preceding period net of consumption and human capital investment, whereas the stock of human capital in every period is determined by the aggregate level of public education in the preceding period. ${ }^{30}$

\subsection{Production of Final Output}

Production occurs within a period according to a neoclassical, constant-returns-to-scale, production technology. The output produced at time $t, Y_{t}$, is

$$
Y_{t}=F\left(K_{t}, H_{t}\right) \equiv H_{t} f\left(k_{t}\right)=A H_{t} k_{t}^{\alpha} ; \quad k_{t} \equiv K_{t} / H_{t} ; \quad \alpha \in(0,1),
$$

where $K_{t}$ and $H_{t}$ are the quantities of physical capital and human capital (measured in efficiency units) employed in production at time $t$, and $A$ is the level of technology. ${ }^{31}$ The production function, $f\left(k_{t}\right)$, is therefore strictly monotonic increasing, strictly concave satisfying the neoclassical boundary conditions that assure the existence of an interior solution to the producers' profitmaximization problem.

Producers operate in a perfectly competitive environment. Given the wage rate per efficiency unit of labor, $w_{t}$, and the rate of return to capital, $r_{t}$, producers in period $t$ choose the level of employment of capital, $K_{t}$, and efficiency units of labor, $H_{t}$, so as to maximize profits. That is, $\left\{K_{t}, H_{t}\right\}=\arg \max \left[H_{t} f\left(k_{t}\right)-w_{t} H_{t}-r_{t} K_{t}\right]$. The producers' inverse demand for factors of

\footnotetext{
${ }^{29}$ Earlier growth models that focus on the role of physical and human capital in the process of development include, for instance, Lucas (1988), Caballe and Santos (1993) and Mulligan and Sala-i-Martin (1993). These models abstract from the analysis of income heterogeneity and credit market imperfections, and therefore, do not study the incentives of the rich to subsidize the education of the poor.

${ }^{30}$ The model abstracts from international factor movements. Land abundance in America have generated incentives for outflow of labor from Europe to America, intensifying the problem of labor scarcity and preventing the use of labor inflow (rather than investment in human capital) as a remedy for labor scarcity. In contrast, as argued by Taylor (1999) and O'Rourke, Taylor and Williamson (1996), international capital outflow from Britain was significant during the 19th century and hence could alleviate some of the need to invest in human capital in order to sustain the profit rates.

${ }^{31}$ The introduction of technological progress would accelerate the rise in wages and may eventually trigger the demise of the class structure even in the absence of education reforms. Nevertheless, educational reforms would have a significant role in expediting the process. Moreover, it should be noted, that consistent with empirical evidence TFP growth over the relevant period for this study is negligible and output growth is based primarily on factor accumulation, as underlined in the proposed theory.
} 
production is therefore

$$
\begin{aligned}
& r_{t}=f^{\prime}\left(k_{t}\right)=\alpha A k_{t}^{\alpha-1} \equiv r\left(k_{t}\right) \\
& w_{t}=f\left(k_{t}\right)-f^{\prime}\left(k_{t}\right) k_{t}=(1-\alpha) A k_{t}^{\alpha} \equiv w\left(k_{t}\right) .
\end{aligned}
$$

\subsection{Individuals}

In every period a generation which consists of a continuum of individuals of measure 1 is born. Each individual has a single parent and a single child. Individuals, within as well as across generations, are identical in their preferences and innate abilities. They may differ, however, in their family wealth and thus, due to borrowing constraints, in their capability to finance investment in human capital in the absence of public education.

Individuals live for two periods. In the first period of their lives individuals devote their entire time for the acquisition of human capital. The acquired level of human capital increases if their time investment is supplemented with capital investment in education. In the second period of their lives, individuals supply their efficiency units of labor and allocate the resulting wage income, along with their interest income, between consumption and transfers to their children.

An individual $i$ born in period $t$ (a member $i$ of generation $t$ ) receives a parental transfer, $b_{t}^{i}$, in the first period of life. A fraction $\tau_{t} \geq 0$ of this capital transfer is collected by the government in order to finance public education, whereas a fraction $1-\tau_{t}$ is saved for future consumption. Individuals devote their first period for the acquisition of human capital. Education is provided publicly free of charge. ${ }^{32}$ The acquired level of human capital increases with the real resources invested in public education. The number of efficiency units of labor of each member of generation $t$ in period $t+1, h_{t+1}$, is a strictly increasing, strictly concave function of the government real expenditure on education per member of generation $t, e_{t} \cdot{ }^{33}$

$$
h_{t+1}=h\left(e_{t}\right),
$$

where $h(0)=1, h^{\prime}(0)=\gamma<\infty$, and $\lim _{e_{t} \rightarrow \infty} h^{\prime}\left(e_{t}\right)=0$. The assumption that the slope of the production function of human capital is finite at the origin along with the assumption that each individual has a minimal level of human capital, $h(0)>0$, even in the absence of a real expenditure on education, assure that under some market conditions investment in human capital

\footnotetext{
${ }^{32}$ As will become apparent, once the level of public education is chosen, individuals have no incentive to acquire private education. In particular, in early stages of development, when the tax rate $\tau_{t}$ equals zero, individuals do not acquire education.

${ }^{33} \mathrm{~A}$ more realistic formulation would link the cost of education to (teachers) wages, which may vary in the process of development. For instance, $h_{t+1}=h\left(e_{t} / w_{t}\right)$ implies that the cost of education is a function of the number of efficiency units of teachers that are used in the education of each individual $i$. As can be derived from section 3.4, under both formulations the optimal expenditure on education, $e_{t}$, is an increasing function of the capital-labor ratio in the economy, and the qualitative results are therefore identical.
} 
is not optimal. ${ }^{34}$

In the second period life, a member $i$ of generation $t$ supplies the acquired efficiency units of labor, $h_{t+1}$, at the competitive market wage, $w_{t+1}$. In addition, the individual receives the gross return on savings, $\left(1-\tau_{t}\right) b_{t}^{i} R_{t+1}$. The individual's second period income, $I_{t+1}^{i}$, is therefore

$$
I_{t+1}^{i}=w_{t+1} h\left(e_{t}\right)+\left(1-\tau_{t}\right) b_{t}^{i} R_{t+1}
$$

where due to complete capital depreciation $R_{t+1} \equiv r_{t+1} \equiv R\left(k_{t+1}\right)$.

Preferences of a member $i$ of generation $t$ are defined over second period consumption, $c_{t+1}^{i}$, and the transfer to their offspring, $b_{t+1}^{i} \cdot{ }^{35}$ They are represented by a non-homothetic, log-linear utility function that generates the property that the average propensity to bequest is an increasing function of wealth: ${ }^{36}$

$$
u_{t}^{i}=(1-\beta) \log c_{t+1}^{i}+\beta \log \left(\bar{\theta}+b_{t+1}^{i}\right),
$$

where $\beta \in(0,1)$ and $\bar{\theta}>0 .{ }^{37}$

Hence, a member $i$ of generation $t$ allocates second period income between consumption, $c_{t+1}^{i}$, and transfers to the offspring, $b_{t+1}^{i}$. That is,

$$
c_{t+1}^{i}+b_{t+1}^{i} \leq I_{t+1}^{i}
$$

The individual chooses the level of second period consumption, $c_{t+1}^{i}$, and a non-negative transfer to the offspring, $b_{t+1}^{i}$, so as to maximize the utility function subject to the second period budget constraint $(6){ }^{38}$

\footnotetext{
${ }^{34}$ These assumptions are necessary in order to assure that in the early stage of development the sole engine of growth is physical capital accumulation and there is no incentive to invest in human capital. It permits, therefore, a sharp presentation of the results regarding institutional transition. The typically assumed Inada condition (i.e., $\gamma$ is infinite) is designed to simplify the exposition by avoiding a corner solution, but it is not a realistic assumption.

${ }^{35}$ For simplicity we abstract from first period consumption. It may be viewed as part of the consumption of the parent.

${ }^{36}$ This utility function represents preferences under which the saving rate is an increasing function of wealth. This classical feature (e.g., Keynes (1920), Lewis (1954), Kaldor (1957)) is consistent with empirical evidence. Dynan, Skinner and Zeldes (2004) find a strong positive relationship between personal saving rates and lifetime income in the United States. They argue that their findings are consistent with models in which precautionary saving and bequest motives drive variations in saving rates across income groups. Furthermore, Tomes (1981) and Menchik and David (1983) find evidence that the marginal propensity to bequeath increases with wealth. The choice of a non-homothetic utility function is necessary to assure that Workers do not invest in physical capital prior to the establishment of public schooling. A choice of a homothetic utility function would not affect the results regarding the effect of capital skill-complementarity on institutional transition, but it would imply that the demise of the class structure would have necessarily occurred even in the absence of education reforms. Nevertheless, even under homothetic preferences, educational reforms would have a significant role in expediting the process.

${ }^{37}$ This form of altruistic bequest motive (i.e., the "joy of giving") is the common form in the recent literature on income distribution and growth. It is supported empirically by Altonji, Hayashi and Kotlikoff (1997). Utility from after tax transfers would reduce intergenerational transfers but would not affect the qualitative results. In particular, under utility from net transfers equation (7) below would be

$$
b_{t+1}^{i}=b\left(I_{t+1}^{i}, \tau_{t+1}\right) \equiv\left\{\begin{array}{lll}
\beta\left(I_{t+1}^{i}-\theta /\left(1-\tau_{t+1}\right)\right) & \text { if } & I_{t+1}^{i}>\theta /\left(1-\tau_{t+1}\right) \\
0 & \text { if } \quad & I_{t+1}^{i} \leq \theta /\left(1-\tau_{t+1}\right)
\end{array}\right.
$$

${ }^{38}$ It should be noted that the transfer, $b_{t+1}^{i}$, is necessarily non-negative due to the assumption that the offspring has no income in the first period of life.
} 
Hence the optimal transfer of a member $i$ of generation $t$ is:

$$
b_{t+1}^{i}=b\left(I_{t+1}^{i}\right) \equiv\left\{\begin{array}{lll}
\beta\left(I_{t+1}^{i}-\theta\right) & \text { if } & I_{t+1}^{i}>\theta \\
0 & \text { if } & I_{t+1}^{i} \leq \theta
\end{array}\right.
$$

where $\theta \equiv \bar{\theta}(1-\beta) / \beta$.

\subsection{Physical Capital, Human Capital, and Output}

This section demonstrates that the stocks of physical and human capital and therefore the level of output are determined by the aggregate level of intergenerational transfers, the level of taxation, and governmental expenditure on public education, in the preceding period.

Let $B_{t}$ denote the aggregate level of intergenerational transfers in period $t$. A fraction $\tau_{t}$ of this capital transfer is collected by the government in order to finance public education, whereas a fraction $1-\tau_{t}$ is saved for future consumption. ${ }^{39}$ The capital stock in period $t+1, K_{t+1}$, is therefore

$$
K_{t+1}=\left(1-\tau_{t}\right) B_{t}
$$

whereas the government tax revenues are $\tau_{t} B_{t}$.

Since population is normalized to 1 , the education expenditure per young individual in period $t, e_{t}$, is

$$
e_{t}=\tau_{t} B_{t}
$$

and the stock of human capital in period $t+1, H_{t+1}$, is therefore

$$
H_{t+1}=h\left(e_{t}\right)=h\left(\tau_{t} B_{t}\right)
$$

Hence, the capital-labor ratio $k_{t+1} \equiv K_{t+1} / H_{t+1}$ is

$$
k_{t+1}=\frac{\left(1-\tau_{t}\right) B_{t}}{h\left(\tau_{t} B_{t}\right)} \equiv k\left(\tau_{t}, B_{t}\right)
$$

where $k\left(0, B_{t}\right)=B_{t}, \quad \partial k\left(\tau_{t}, B_{t}\right) / \partial \tau_{t}<0, \quad \partial k\left(\tau_{t}, B_{t}\right) / \partial B_{t}>0,{ }^{40}$ and the output per-worker in period $t+1$ is

$$
y_{t+1}=A\left[\left(1-\tau_{t}\right) B_{t}\right]^{\alpha} h\left(\tau_{t} B_{t}\right)^{1-\alpha} \equiv y\left(\tau_{t}, B_{t}\right) .
$$

\footnotetext{
${ }^{39}$ As will become apparent, this linear tax structure is the simplest structure that would generate the transition from a class society. It assures that the chosen level of taxation is independent of the structure of the political system. That is, independent of the distribution of political power or voting rights among members of society. Furthermore, Capitalists could have not effectively forced the poor to finance their own education due to the proximity of the income of the poor to the subsistence level of consumption and the positive effect of income of the outcome of the education process.

${ }^{40} \partial k\left(\tau_{t}, B_{t}\right) / \partial B_{t}>0$ if and only if $h\left(e_{t}\right)-h^{\prime}\left(e_{t}\right) e_{t}>0$, which is satisfied given the strict concavity of $h\left(e_{t}\right)$ and the positivity of $h(0)$.
} 


\subsection{Optimal Taxation}

This section derives the optimal tax rate and therefore the optimal expenditure on education from the viewpoint of each individual in society. It demonstrates that as long as taxation is used in order to finance public schooling, there is a consensus in society regarding the desirable tax rate. If the government would be engaged in direct transfers from the rich to the poor in addition to the provision of public schooling, then a conflict would emerge between the classes regarding the desirable tax rate. This would perhaps add some realism, but would obscure unnecessarily the focus on the role of cooperative forces in the demise of the class structure.

Given that the indirect utility function is a strictly increasing function of the individual's second period wealth, the optimal tax rate, $\tau_{t}^{i}$, from the viewpoint of member $i$ of generation $t$, (and hence the optimal expenditure on education, $e_{t}=\tau_{t}^{i} B_{t}$ from the viewpoint of this individual, given $B_{t}$ ) would maximize the individual's second period wealth, $I_{t+1}^{i}$.

$$
\tau_{t}^{i}=\arg \max \left[w_{t+1} h\left(\tau_{t}^{i} B_{t}\right)+\left(1-\tau_{t}^{i}\right) b_{t}^{i} R_{t+1}\right],
$$

where $w_{t+1}=w\left(k_{t+1}\right)$ and $R_{t+1}=R\left(k_{t+1}\right)$.

As follow from (13), noting (2) and (11) the optimal tax rate from the viewpoint of a member $i$ of generation $t, \tau_{t}^{i}$, is given by ${ }^{41}$

$$
\begin{gathered}
w\left(k_{t+1}\right) h^{\prime}\left(\tau_{t}^{i} B_{t}\right)=R\left(k_{t+1}\right) \quad \text { for } \quad \tau_{t}^{i}>0 \\
w\left(k_{t+1}\right) \gamma \leq R\left(k_{t+1}\right) \quad \text { for } \quad \tau_{t}^{i}=0,
\end{gathered}
$$

where $k_{t+1}=k\left(\tau_{t}, B_{t}\right)$. Hence, given $B_{t}, \tau_{t}^{i}$ is determined independently of $b_{t}^{i}$, and is therefore identical for all $i{ }^{42}$ That is $\tau_{t}^{i}=\tau_{t}^{*}$ for all $i$. Furthermore, there exists a unique capital-labor ratio $\widetilde{k}$, below which $\tau_{t}^{i}=0$. That is, $R(\widetilde{k})=w(\widetilde{k}) \gamma$.

Lemma 1 (a) The optimal tax rate in period $t, \tau_{t}^{*}$, is identical from the viewpoint of all member of generation $t$ and is uniquely determined.

$$
\tau_{t}^{*}=\tau\left(B_{t}\right)\left\{\begin{array}{lll}
>0 & \text { for } & B_{t}>\widetilde{k} \\
=0 & \text { for } & B_{t} \leq \widetilde{k}
\end{array}\right.
$$

\footnotetext{
${ }^{41}$ Substituting (2) and (11) into (13),

$$
\tau_{t}^{i}=\arg \max \left(1-\tau_{t}^{i}\right)^{\alpha} h\left(\tau_{t}^{i} B_{t}\right)^{1-\alpha} B_{t}{ }^{\alpha}\left[1-\alpha+\alpha b_{t}^{i} / B_{t}\right]
$$

The conditions in (14) follow from the optimization problem above, using (2).

${ }^{42}$ The unanimous agreement on the tax rate is a result of the linear tax rate and the unit elasticity of substitution between human and physical capital in production. Given a Cobb-Douglas production function, the shares of labor and capital are constant and wage and capital income are therefore maximized if output is maximized. If the elasticity of substitution would be larger than unity, then the poor would prefer higher taxes, whereas if the elasticity of substitution is smaller than unity, then the rich would prefer higher taxes.
} 
$\widetilde{k}=\alpha /(1-\alpha) \gamma$

(b) The optimal expenditure on public education, $e_{t}=\tau\left(B_{t}\right) B_{t} \equiv e\left(B_{t}\right)$ from the viewpoint of each member of generation $t$ is strictly increasing in $B_{t}$, for $B_{t}>\widetilde{k}$.

Proof. Noting (2), (11) and (14) it follows from the properties of $h\left(\tau_{t} B_{t}\right)$ that $\tau_{t}^{*}$ is uniquely determined by $B_{t}$ and $e^{\prime}\left(B_{t}\right)>0$, where as follows from the definition of $\widetilde{k}$ and $(2), \widetilde{k}=\alpha /(1-\alpha) \gamma$.

Hence, since the optimal tax rate in period $t$ is identical from the viewpoint of each member of generation $t$, it follows that under any political structure, the chosen tax rate in period $t$ is

$$
\tau_{t}=\tau_{t}^{*}=\tau\left(B_{t}\right)
$$

Proposition 1 The tax rate in period $t, \tau_{t}$ is

$$
\tau_{t}\left\{\begin{array}{lll}
>0 & \text { for } & k_{t+1}>\widetilde{k} \\
=0 & \text { for } & k_{t+1} \leq \widetilde{k} .
\end{array}\right.
$$

Proof. Since $h(0)=1$, it follows from (11) (14) and Lemma 1 that $k_{t+1}=B_{t}$ for $B_{t} \leq \widetilde{k}$ and hence for $k_{t+1} \leq \widetilde{k}$. Thus the Proposition follows.

Corollary 1 The chosen level of taxation in every period maximizes output per-worker in the following period. That is,

$$
\tau_{t}=\arg \max y_{t+1} \equiv \arg \max y\left(\tau_{t}, B_{t}\right)
$$

Proof. Maximizing $y\left(\tau_{t}, B_{t}\right)$ with respect to $\tau_{t}$ yield the optimality conditions given by (14). That is, the optimality conditions for the desired level of taxation from the viewpoint of each individual.

Hence, as long as the rate of return to human capital is lower than the rate of return on physical capital (i.e., as long as $k_{t+1} \leq \widetilde{k}$ ) the chosen level of investment in public education is zero - the level of investment that maximizes output per-worker. Once the rate of return to human capital equals the rate of return on physical capital (i.e., once $k_{t+1}>\widetilde{k}$ ) the chosen investment in public education is positive and it maximizes output per-worker.

\subsection{The Dynamical System}

This section derives the properties of the dynamical system that governs the evolution of the economy in the transition from a class society to a classless society. It demonstrates that the evolution of the economy is fully determined by the evolution of intergenerational transfer within classes in society. 
Suppose that in period 0 the economy consists of two groups of individuals in their first period of their lives - Capitalists and workers. They are identical in their preferences and differ only in their initial wealth. The Capitalists, denoted by $R$ (Rich), are a fraction $\lambda$ of all individuals in society, who equally own the entire initial stock of wealth. The Workers, denoted by $P$ (Poor), are a fraction $1-\lambda$ of all individuals in society, who have no ownership over the initial physical capital stock. ${ }^{43}$ Since individuals are initially homogenous within a group, the uniqueness of the solution to their optimization problem assures that their offspring who acquire the same level of education and are taxed equally are homogenous as well. Hence, in every period a fraction $\lambda$ of all adults are homogenous descendents of the Capitalists, denoted by members of group $R$, and a fraction $1-\lambda$ are homogenous descendents of Workers, denoted by members of group $P$.

The optimization of groups $P$ and $R$ of generation $t-1$ in period $t>0$, determines the aggregate intergenerational transfers in period $t, B_{t}$.

$$
B_{t}=\lambda b_{t}^{R}+(1-\lambda) b_{t}^{P} \equiv B\left(b_{t}^{R}, b_{t}^{P}\right)
$$

where $b_{t}^{i}$ is the intergenerational transfer of each member of group $i$ in period $t ; i=P, R$.

Hence, the capital-labor ratio in period $t+1, k_{t+1}$, is fully determined by the intergenerational transfers of the two groups. As follows from (11), (15), (16), and Proposition 1,

$$
k_{t+1}=\frac{\left[1-\tau\left(B_{t}\right)\right] B_{t}}{h\left[\tau\left(B_{t}\right) B_{t}\right]} \equiv \kappa\left(b_{t}^{R}, b_{t}^{P}\right)
$$

where as follows from (2) and (14), and the properties of (11), $\partial \kappa / \partial b_{t}^{i}>0, i=R, P$. Furthermore, $\kappa(0,0)=0$ (since in the absence of transfers and hence savings the capital stock in the subsequent period is zero).

Since members of group $R$ equally own the entire initial stock of wealth in period 0 and members of group $P$ have no ownership over the initial stock of wealth, it follows that $b_{0}^{R}>0$ and $b_{0}^{p}=0$.

Lemma 2 If $b_{0}^{R}<\widetilde{k} / \lambda$ then $k_{1}<\widetilde{k}$ and thus there is no investment in public education in period 0.

Proof. Since $b_{0}^{p}=0,(11),(16)$ and Lemma 1, given the properties of (3), imply that $k_{1}=B_{0}=\lambda b_{0}^{R}$. Hence, it follows that $k_{1}<\widetilde{k}$ and thus, as follows from Proposition $1, \tau_{0}=0$.

Consistently with empirical evidence about the process of development, it is therefore assumed that

$$
b_{0}^{R}<\widetilde{k} / \lambda,
$$

\footnotetext{
${ }^{43}$ As will become apparent this class distinction will dissipate over time. In particular, descendents of the working class will ultimately own some physical capital.
} 
namely, there is no investment in public education in the early stage of development.

The evolution of transfers within each group $i=R, P$, as follows from (7), is given by

$$
\left.b_{t+1}^{i}=\max \left\{\beta\left[w\left(k_{t+1}\right) h\left(\tau\left(B_{t}\right) B_{t}\right)\right)+\left(1-\tau\left(B_{t}\right)\right) b_{t}^{i} R\left(k_{t+1}\right)-\theta\right], 0\right\} ; \quad i=R, P .
$$

Since $k_{t+1}=\kappa\left(b_{t}^{R}, b_{t}^{P}\right)$, and $B_{t}=B\left(b_{t}^{R}, b_{t}^{P}\right)$, the evolution of transfers of each of the two groups is fully determined by the evolution of transfers of both types of dynasties. Namely,

$$
\begin{aligned}
b_{t+1}^{i} & =\max \left\{\beta\left[w\left(\kappa\left(b_{t}^{R}, b_{t}^{P}\right)\right) h\left(\tau\left(B\left(b_{t}^{R}, b_{t}^{P}\right)\right) B\left(b_{t}^{R}, b_{t}^{P}\right)\right)\right)+\left(1-\tau\left(B\left(b_{t}^{R}, b_{t}^{P}\right)\right)\right) b_{t}^{i} R\left(\kappa\left(b_{t}^{R}, b_{t}^{P}\right)\right)-\theta(1,19)\right. \\
& \equiv \psi^{i}\left(b_{t}^{R}, b_{t}^{P}\right) ; \quad i=R, P .
\end{aligned}
$$

Thus, the dynamical system is uniquely determined by the joint-evolution of the intergenerational transfers of Workers, $P$ and Capitalists, $R$. Hence, the evolution of the economy is given by the sequence $\left\{b_{t}^{P}, b_{t}^{R}\right\}_{t=0}^{\infty}$ that satisfies in every period

$$
\begin{aligned}
& b_{t+1}^{P}=\psi^{P}\left(b_{t}^{R}, b_{t}^{P}\right) ; \\
& b_{t+1}^{R}=\psi^{R}\left(b_{t}^{R}, b_{t}^{P}\right),
\end{aligned}
$$

where $b_{0}^{p}=0$ and $b_{0}^{R}>0$.

\section{The Process of Development}

This section analyzes the endogenous demise of the Capitalists-Workers class structure as the economy evolves from early to mature stages of development. As will become apparent, if additional plausible restrictions are imposed on the basic model, the economy endogenously evolves through two fundamental regimes:

- Regime I: This early stage of development, is characterized by a stable class structure. Capitalists generate a higher rate of return from a direct investment in physical capital, rather than from supporting the education of Workers that would complement their capital in the production process. Capitalists therefore have no incentive to financially support the education of the Workers.

- Regime II: These later stages of development are characterized by the onset of the gradual demise of the Capitalists-Workers class structure. The importance of human capital in sustaining the profits of Capitalists increases sufficiently. The Capitalists find it beneficial to financially support public education, and ultimately Workers, as well as Capitalists, are engaged in physical capital accumulation. 


\subsection{Regime I: Physical Capital Accumulation}

This early stage of development is characterized by a stable class structure. Capitalists generate a higher rate of return from a direct investment in physical capital, rather than from supporting the education of Workers that would complement their capital in the production process. Capitalists therefore have no incentive to financially support the education of the Workers.

Regime $\mathrm{I}$ is defined as the time interval $0 \leq t<\tilde{t}$, where $\widetilde{t}+1$ is the first period in which the capital labor ratio exceeds $\widetilde{k}$ (i.e., $\widetilde{t}$ is the first period in which investment in human capital takes place). In this early stage of development the capital-labor ratio in period $t+1, k_{t+1}$, which determines the investment in public education in period $t$, is lower than $\widetilde{k}$. As follows from Proposition 1 and Corollary 1, the tax rate is zero, there is no public education, and both groups of individuals acquire only basic skills. That is, $H_{t+1}=h(0)=1$.

Let $\check{k}$ be the level of the capital-labor ratio such that $w(\check{k})=\theta$. As follows from $(4), \check{k}$ is the critical level of the capital-labor ratio in time $t+1$ below which in the absence of public investment in education in period $t$ individuals who do not receive transfers from their parents in period $t$ do not transfer income to their offspring in period $t+1$. That is, $I_{t+1}^{i} \leq \theta$ and therefore $b_{t+1}^{i}=0$.

In order to assure that investment in human capital will begin in a period where the poor do not invest in physical capital, it is assumed therefore that ${ }^{44}$

$$
\widetilde{k} \leq \check{k}
$$

As follows from $(2), \check{k}=[\theta /(1-\alpha) A]^{1 / \alpha}$. Since $\widetilde{k}=\alpha /(1-\alpha) \gamma$, Assumption A2 implies therefore that $\gamma>\left(\alpha^{\alpha}(1-\alpha)^{1-\alpha} A / \theta\right)^{1 / \alpha}$.

Lemma 3 Under Assumptions A1 and A2, there are no intergenerational transfers among workers (i.e., $b_{t}^{P}=0$ ) as long as public education is not established, i.e.,

$$
b_{t}^{P}=0 \quad \text { for } \quad 1 \leq t \leq \tilde{t}
$$

Proof. As follows from Proposition 1, the definition of $\widetilde{t}$, and Assumption A1 that assures that $\tilde{t}>1$, for $0 \leq t<\tilde{t}$, there is no investment in public education and hence $h_{t+1}=1$. Hence, since Assumption A2 implies that $k_{t} \leq \check{k}$ and therefore $w\left(k_{t}\right) \leq \theta$, it follows that $b_{t+1}^{P}=$ $\max \left[\beta\left[w\left(k_{t+1}\right)-\theta\right], 0\right]=0$ if $b_{t}^{P}=0$. Since $b_{0}^{P}=0$ it follows therefore that $b_{t}^{P}=0$ for $1 \leq t \leq \widetilde{t}$.

The capital-labor ratio in period $t+1$, as follows from (16), (17), proposition 1, and Lemma 3, is

$$
k_{t+1}=\kappa\left(b_{t}^{R}, 0\right)=\lambda b_{t}^{R} \quad \text { for } \quad t \in[0, \widetilde{t})
$$

\footnotetext{
${ }^{44}$ This assumption is designed to simplify the presentation of the results. As will become apparent, even if Assumption A2 would be violated, the Capitalists would have an incentive to support the education of Workers.
} 
and the level of output per-worker in period $t+1, y_{t+1}$, as follows from (1) and (22), is ${ }^{45}$

$$
y_{t+1}=A\left[\lambda b_{t}^{R}\right]^{\alpha} \quad \text { for } \quad t \in[0, \widetilde{t})
$$

\section{The Dynamics of Output Per-Worker}

The evolution of output per-worker in Regime I is driven in this regime by physical capital accumulation. The income of the Workers is not sufficiently high to permit intergenerational transfers and therefore savings, and the evolution of intergenerational transfers among Capitalists determines therefore the accumulation of physical capital and thus the growth of output per-worker over Regime I.

The evolution of the intergenerational transfers in the economy, as follows from (21) and Lemma 3 , are

$$
\left.\begin{array}{l}
b_{t+1}^{R}=\psi^{R}\left(b_{t}^{R}, 0\right)=\max \left[\beta\left[w\left(\lambda b_{t}^{R}\right)+b_{t}^{R} R\left(\lambda b_{t}^{R}\right)-\theta\right], 0\right] ; \\
b_{t+1}^{P}=0,
\end{array}\right\} \quad \text { for } \quad t \in[0, \widetilde{t})
$$

where $b_{0}^{R}>0$ is given. Hence in Regime I the dynamical system is fully determined by the evolution of transfers across members of group $R$.

Hence, the evolution of the entire dynamical system in Regime I can be represented by the evolution of output per-worker. Since the aggregate income of the Capitalists (group $R$ ) is $(\lambda(1-\alpha)+\alpha) y_{t}$, (where $\alpha$ is the share of capital in total output that is fully owned by the Capitalists and $\lambda(1-\alpha)$ is the labor share

of group $R$ ), it follows from (7), (23) and (24) that the evolution of output per-worker in the time period $t \in[0, \widetilde{t})$ is

$$
y_{t+1}=\max \left[A\left\{\beta\left\{[\lambda(1-\alpha)+\alpha] y_{t}-\lambda \theta\right\}\right\}^{\alpha}, 0\right] \equiv \phi^{I}\left(y_{t}\right), \quad \text { for } \quad y_{t} \in[0, \widetilde{y}),
$$

where $\widetilde{y}=A \widetilde{k}^{\alpha}$.

In order to assure that the economy would ultimately take off from Regime I to Regime II (i.e., in order to assure that consistently with empirical evidence the process of development is marked by human capital accumulation) it is assumed that the technology is sufficiently productive. That is,

$$
A>\widetilde{A}
$$

where $\widetilde{A}$ is the critical level of technology such that $\phi^{I}(\widetilde{y})=\widetilde{y} \cdot{ }^{46}$

\footnotetext{
${ }^{45}$ Note that since the size of the population is $1, Y_{t+1}=y_{t+1}$.

${ }^{46}$ As follows from (25), $\widetilde{A}=\left[1+\lambda(1-\alpha)^{\alpha} \beta \gamma^{\alpha} \theta \alpha^{-\alpha}\right] /[\beta(\alpha+(1-\alpha) \lambda)]$. It should be noted that a sufficiently high level of A that satisfies Assumption A3 does not violate Assumption A2. An increase in $A$ and $\gamma^{\alpha}$ holding their ratio unchanged, does not affect $\mathrm{A} 2$ and increases $A$ relative to $\widetilde{A}$.
} 
Figure 4 depicts the properties of $\phi^{I}\left(y_{t}\right)$ over the interval $y_{t} \in(0, \widetilde{y}]$, as established in the following Lemma and Corollary.

Lemma 4 Under Assumptions A2 and A3, there exists $\underline{y} \in(0, \widetilde{y}) ; \widetilde{y}=A \widetilde{k}^{\alpha}$, such that the properties of $\phi^{I}\left(y_{t}\right)$ in the interval $y_{t} \in[0, \widetilde{y}]$ are

$$
\begin{array}{ll}
\phi^{I}\left(y_{t}\right)=0 & \text { for } y_{t} \leq y \\
\partial \phi^{I}\left(y_{t}\right) / \partial y_{t}>0 & \text { for } \quad \underline{y}<y_{t} \leq \widetilde{y} \\
\partial^{2} \phi^{I}\left(y_{t}\right) / \partial\left[y_{t}\right]^{2}<0 & \text { for } \quad \underline{y}<y_{t} \leq \widetilde{y} \\
\phi^{I}\left(y_{t}\right)>y_{t} & \text { for } y_{t}=\widetilde{y}
\end{array}
$$

Proof. As follows from (25), $\phi^{I}\left(y_{t}\right)=0$ for $y_{t} \leq \underline{y}=\lambda \theta /(\lambda(1-\alpha)+\alpha)$, and $\partial \phi^{I}\left(y_{t}\right) / \partial y_{t}>0$, and $\partial^{2} \phi^{I}\left(y_{t}\right) / \partial\left[y_{t}\right]^{2}<0$ for $\underline{y}<y_{t} \leq \widetilde{y}=A\{\alpha /[(1-\alpha) \gamma]\}^{\alpha}$. Consistently with Assumption A2, there exist a sufficiently small $\gamma$ such that $\widetilde{y}>\underline{y} .{ }^{47}$ Furthermore, Assumption A3 assures that $\phi^{I}\left(y_{t}\right)>y_{t}$ for $y_{t}=\widetilde{y}$

Corollary 2 Under Assumptions A2 and A3, the dynamical system $\phi^{I}\left(y_{t}\right)$ has two steady-state equilibria in the interval $y_{t} \in[0, \widetilde{y}] ;$ A locally stable steady-state, $\bar{y}=0$, and an unstable steadystate, $\bar{y}^{u} \in(\underline{y}, \widetilde{y})$.

As follows from the Corollary, if $y_{t}<\bar{y}^{u}$ then output per worker contract over time and the system converges to the steady-state equilibrium $\bar{y}=0$. If $y_{t}>\bar{y}^{u}$ then output per worker expands over the entire interval $\left(\bar{y}^{u}, \widetilde{y}\right]$, crossing into Regime II. Hence, in order to assure that the process of development takes off it is assumed that

$$
y_{0} \in\left(\bar{y}^{u}, \widetilde{y}\right) .
$$

implying that $b_{0}^{R} \in\left(\left[\bar{y}^{u} / A \lambda^{\alpha}\right]^{1 / \alpha},\left[\widetilde{y} / A \lambda^{\alpha}\right]^{1 / \alpha}\right)=\left(\left[\bar{y}^{u} / A \lambda^{\alpha}\right]^{1 / \alpha}, \widetilde{k} / \lambda\right)$. Hence, Assumption A1 is a subset of Assumption A4.

Thus, in Regime I, output per-capita increases monotonically over time due to the process of capital accumulation. Consistent with historical evidence, the wage-rental ratio, which is uniquely determined by the capital-labor ratio, increases as well. Moreover, the accumulation of physical capital by the Capitalists in Regime I raises gradually the potential role of the education of the Workers in sustaining the profit rates of the Capitalists. Ultimately, the Capitalists find it beneficial to support public education, and the economy enters into Regime II where the process of development is fueled by human capital accumulation as well as physical capital accumulation.

\footnotetext{
${ }^{47}$ If $\underline{\gamma}<\gamma<\bar{\gamma}$ where $\underline{\gamma}=\left[\alpha^{\alpha}(1-\alpha)^{1-\alpha} A / \theta\right]^{1 / \alpha}<\bar{\gamma}=\left[\alpha^{\alpha}(1-\alpha)^{1-\alpha} A / \theta+\alpha^{1+\alpha}(1-\alpha)^{-\alpha} A / \lambda \theta\right]^{1 / \alpha}$, then Assumption $\mathrm{A} \overline{2}$ and $\widetilde{y}>y$ are satisfied simultaneously. Furthermore, as discussed in the previous footnote, Assumptions A3 and $\widetilde{y}>\underline{y}$ are mutually consistent.
} 


\subsection{Regime II: Education and the Decline of the Class Structure}

These later stages of development are characterized by the onset of the gradual demise of the Capitalists-Workers class structure. The importance of human capital in sustaining the profits of Capitalists increases sufficiently. The Capitalists find it beneficial to financially support public education, and ultimately Workers, as well as Capitalists, are engaged in physical capital accumulation.

\subsubsection{Stage I: The Birth of Public Schooling}

In Stage I of Regime II, the economy witnesses the birth of public education. The Capitalists invest in human capital as well as in physical capital, whereas workers acquire education financed by the Capitalists. The wage income, however, is not sufficiently high so as to permit physical capital accumulation by the Workers.

Stage I of Regime II is defined as the time interval $\widetilde{t} \leq t<\widehat{t}$, where $\widehat{t}$ is the first time period in which Workers (group $P$ ) are engaged in intergenerational transfers, permitting physical capital accumulation by the offspring. Although workers acquire education financed by the Capitalists, their income level is not sufficiently high so as to permit transfer to their offspring.

The capital-labor ratio in period $t+1$, as follows from (16), (17), proposition 1, and Lemma 3,

$$
k_{t+1}=\kappa\left(b_{t}^{R}, 0\right)=\frac{\left(1-\tau_{t}\right) \lambda b_{t}^{R}}{h\left(\tau_{t} \lambda b_{t}^{R}\right)} \quad \text { for } \quad t \in[\widetilde{t}, \widehat{t}) .
$$

where $\partial \kappa\left(b_{t}^{R}, 0\right) / \partial b_{t}^{R}>0$. The level of output per-worker in period $t+1, y_{t+1}$, as follows from (1) and $(26)$, is

$$
y_{t+1}=A\left[\left(1-\tau_{t}\right) \lambda b_{t}^{R}\right]^{\alpha}\left[h\left(\tau_{t} \lambda b_{t}^{R}\right)\right]^{1-\alpha} \quad \text { for } \quad t \in[\widetilde{t}, \widehat{t}) .
$$

\section{The Dynamics of Output Per-Worker}

The evolution of output per-worker in Stage I of Regime II is driven by the accumulation of human capital as well as physical capital. The income of the Workers is still not sufficiently high to permit intergenerational transfers. Intergenerational transfers among the Capitalists are the sole source of physical capital accumulation, as well as of governmental expenditure on public education, and they determine therefore the growth of output per-worker over Stage I of Regime II.

The evolution of the economy in the time interval $\widetilde{t} \leq t<\widehat{t}$, as follows from (21), is given by

$$
\left.\begin{array}{l}
b_{t+1}^{R}=\psi^{R}\left(b_{t}^{R} ; 0\right)=\beta\left[w\left(k_{t+1}\right) h\left(\tau_{t} \lambda b_{t}^{R}\right)+\left(1-\tau_{t}\right) b_{t}^{R} R\left(k_{t+1}\right)-\theta\right] \\
b_{t+1}^{P}=\psi^{P}\left(b_{t}^{R} ; 0\right)=0
\end{array}\right\} \quad \text { for } \quad t \in[\widetilde{t}, \widehat{t}),
$$

where $k_{t+1}=\kappa\left(b_{t}^{R}, 0\right)$. 
Hence, the evolution of the entire dynamical system in Stage I of Regime II can be represented by the evolution of output per-worker. Since the aggregate income of the Capitalists (group $R$ ) is $(\lambda(1-\alpha)+\alpha) y_{t}$, as is the case in Regime I, it follows from (7) (23) and (28) that the evolution of output per-worker in the time period $t \in[\widetilde{t}, \widehat{t})$ is,

$$
\begin{aligned}
y_{t+1} & =A\left\{\left(1-\tau_{t}\right) \beta\left\{[\lambda(1-\alpha)+\alpha] y_{t}-\lambda \theta\right\}\right\}^{\alpha}\left\{h\left(\tau_{t} \beta\left\{[\lambda(1-\alpha)+\alpha] y_{t}-\lambda \theta\right\}\right)\right\}^{1-\alpha} \\
& \equiv \phi^{I I}\left(y_{t}\right) \quad \text { for } \quad y_{t} \in[\widetilde{y}, \widehat{y}),
\end{aligned}
$$

where $\widetilde{y}=A \widetilde{k}^{\alpha}, \tau_{t}=\arg \max \phi^{I I}\left(y_{t}\right)$, and $\widehat{y}=\theta /(1-\alpha)$, is the critical level of the output perworker such that the income level of individuals who do not receive transfer from their parents (i.e., members of group $P$ ) equals $\theta$. As follows from (4), as long as $y_{t}<\widehat{y}$, the Workers (members of group $P$ ) do not transfer income to their offspring. Hence, since $\widetilde{y}=A\{\alpha /[(1-\alpha) \gamma]\}^{\alpha}$, it follows from assumption A2 that $\widehat{y}>\widetilde{y}$.

In order to assure that the economy would ultimately take off from Stage I to Stage II within Regime II it is assumed that the technology is sufficiently productive. That is,

$$
A \geq \widehat{A} \equiv \frac{\theta^{1-\alpha}}{\alpha^{\alpha} \beta^{\alpha}(1-\alpha)^{1-\alpha}}
$$

where as established in the following Lemma, $\widehat{A}$ is a sufficiently high level of technology such that $\phi^{I I}(\widehat{y})>\widehat{y}^{48}$

If Assumption A5 is violated then there are two feasible scenarios. The economy may converge to a steady-state equilibrium in the interval $(\widetilde{y}, \widehat{y})$ with public education, where individuals are identical in their level of human capital and in their wage income, but they differ in their level of wealth. Alternatively, the economy may proceed, nevertheless, to a long-run steady-state equilibrium above $\widehat{y}$, where offspring of the Capitalists and the Workers are indistinguishable.

Figure 4 depicts the properties of $\phi^{I I}\left(y_{t}\right)$ over the interval $y_{t} \in[\widetilde{y}, \widehat{y}]$, as derived in the following Lemma and Corollary.

Lemma 5 Under Assumptions A2, A3 and A5, the properties of $\phi^{I I}\left(y_{t}\right)$ in the interval $y_{t} \in[\widetilde{y}, \widehat{y}]$ are

$$
\begin{aligned}
& \partial \phi^{I I}\left(y_{t}\right) / \partial y_{t}>0 \\
& \partial^{2} \phi^{I I}\left(y_{t}\right) / \partial y_{t}^{2}<0 \\
& \partial \phi^{I I}(\tilde{y}) / \partial y_{t}=\partial \phi^{I}(\tilde{y}) / \partial y_{t} \\
& \phi^{I I}\left(y_{t}\right)>y_{t}
\end{aligned}
$$

Proof.

$\partial \phi^{I I}\left(y_{t}\right) / \partial y_{t}>0$ and $\partial^{2} \phi^{I I}\left(y_{t}\right) / \partial y_{t}^{2}<0$, and $\partial \phi^{I I}(\tilde{y}) / \partial y_{t}=\partial \phi^{I}(\tilde{y}) / \partial y_{t}$ as follows from (29) and (25) noting that $h(e)$ is strictly concave and $\tau_{t}=\arg \max y_{t+1}$.

${ }^{48}$ Assumptions A3 and A5 imply that $A \geq \max [\widetilde{A}, \widehat{A}]$, where, $\widetilde{A}>\widehat{A} \leftrightarrow \gamma>\left[\frac{\theta^{1-\alpha} \beta(\alpha+(1-\alpha) \lambda)-\alpha^{\alpha} \beta^{\alpha}(1-\alpha)^{1-\alpha}}{\lambda \theta \alpha^{2 \alpha} \beta^{1+\alpha}(1-\alpha)}\right]^{1 / \alpha}$. 
Since $\tau_{t}=\arg \max y_{t+1}$, it follows from Lemma 4 that $\phi^{I I}(\widetilde{y})=\phi^{I}(\widetilde{y})>\widetilde{y}$. Moreover, for $y_{t} \in[\widetilde{y}, \widehat{y}]$, $y_{t+1}=\phi^{I I}\left(y_{t}\right)>A\left\{\beta\left\{[\lambda(1-\alpha)+\alpha] y_{t}-\lambda \theta\right\}\right\}^{\alpha}$ (i.e., $y_{t+1}$ is larger than the output per worker for $\tau_{t}=0$.) Since $(1-\alpha) y_{t} \leq \theta$ for $y_{t} \in[\widetilde{y}, \widehat{y}]$, it follows that $A\left\{\beta\left\{[\lambda(1-\alpha)+\alpha] y_{t}-\lambda \theta\right\}\right\}^{\alpha} \geq$ $A\left[\beta\left(y_{t}-\theta\right)\right]^{\alpha}$. Hence, noting that $\widehat{y}=\theta /(1-\alpha)$, it follows that $\phi^{I I}\left(y_{t}\right)>A\left(\frac{\beta \theta \alpha}{1-\alpha}\right)^{\alpha}$, and therefore

$\phi^{I I}(\widehat{y})>\widehat{y}$ if $A\left(\frac{\beta \theta \alpha}{1-\alpha}\right)^{\alpha}>\frac{\theta}{1-\alpha}$ and thus if $A>\widehat{A}$ (which is satisfied by A5. Thus, since $\phi^{I I}(\widetilde{y})>\widetilde{y}$, $\phi^{I I}(\widehat{y})>\widehat{y}$ and $\partial^{2} \phi^{I I}\left(y_{t}\right) / \partial y_{t}^{2}<0$, it follows that $\phi^{I I}\left(y_{t}\right)>y_{t}$ for all $y_{t} \in[\widetilde{y}, \widehat{y}]$.

Corollary 3 The dynamical system $\phi^{I I}\left(y_{t}\right)$ has no steady-state equilibria in the interval $y_{t} \in[\widetilde{y}, \widehat{y}]$.

The dynamical system $\phi^{I I}\left(y_{t}\right)$ has no steady-state equilibria in the interval $y_{t} \in[\widetilde{y}, \widehat{y}]$ and the transfers within each dynasty of type $R$ expand over the entire interval crossing into Stage II.

Hence, in Stage I of Regime II, the economy witnesses the birth of public education. The Capitalists invest in physical capital, and workers as well as the Capitalists acquire education financed by the Capitalists. The wage income, however, is not sufficiently high so as to permit physical capital accumulation by the Workers. During Stage I of Regime II, the accumulation of physical and human capital increases wage income further, and ultimately the economy enters Stage II of Regime II in which the wage income is sufficiently high so as to permit the accumulation of physical capital by the Workers.

\subsubsection{Stage II: The Demise of the Class Society}

The accumulation of physical and human capital during Stage I of Regime II, increases wage income further and ultimately, the economy enters Stage II of Regime II in which the wage income is sufficiently high so as to permit the accumulation of physical capital by the Workers.

Stage II of Regime II is defined as $t \geq \widehat{t}$. In this time interval all individuals acquire education and transfer income to their offspring.

The level of output per-worker in Stage II of Regime II, exceeds $\widehat{y}$ and the wage income of all members of society exceeds $\theta$. Hence, it follows from (16) and (7), that

$$
B_{t}=\lambda b_{t}^{R}+(1-\lambda) b_{t}^{P}=\beta\left[y_{t}-\theta\right]
$$

The capital-labor ratio in period $t+1$, as follows from (11) and (30), is therefore

$$
k_{t+1}=\frac{\left(1-\tau_{t}\right) \beta\left[y_{t}-\theta\right]}{h\left(\tau_{t} \beta\left[y_{t}-\theta\right]\right)} \quad \text { for } \quad t \in[\widehat{t}, \infty) .
$$

and the level of output per-worker in period $t+1, y_{t+1}$, as follows from (1) and (31), is

$$
y_{t+1}=A\left[\left(1-\tau_{t}\right) \beta\left[y_{t}-\theta\right]\right]^{\alpha}\left[h\left(\tau_{t} \beta\left[y_{t}-\theta\right]\right)\right]^{1-\alpha} \text { for } \quad y_{t}>\widehat{y} .
$$




\section{The Evolution of Output Per-Worker}

The evolution of output per-worker in Stage II of Regime II is driven by the accumulation of human capital as well as physical capital. The income of the Workers is sufficiently high to permit intergenerational transfers and the Workers as well as the Capitalists contribute to physical capital accumulation and governmental expenditure on public education, and they determine therefore the growth of output per-worker over Stage II of Regime II.

The evolution of output per worker in Stage II of Regime II is independent of the distribution of intergenerational transfers across classes and hence the evolution of the economy can be fully characterized by the evolution of output per-worker. As follows from (1) and (31), the evolution of output per worker over the time interval $t>\widehat{t}$ is

$$
y_{t+1}=A\left[\left(1-\tau_{t}\right) \beta\left[y_{t}-\theta\right]\right]^{\alpha}\left[h\left(\tau_{t} \beta\left[y_{t}-\theta\right]\right)\right]^{1-\alpha} \equiv \phi^{I I I}\left(y_{t}\right) \quad \text { for } \quad y_{t}>\widehat{y} .
$$

where $\tau_{t}=\arg \max \phi^{I I I}\left(y_{t}\right)$, and therefore $\partial \phi^{I I I}\left(y_{t}\right) / \partial y_{t}>0$. Furthermore, $\partial \phi^{I I}(\hat{y}) / \partial y_{t}<\partial \phi^{I I I}(\hat{y}) / \partial y_{t}$, and it follows from the concavity and the boundary conditions of $h(e)$ and the aggregate production function that $\partial^{2} \phi^{I I I}\left(y_{t}\right) / \partial y_{t}^{2}<0$, and $\lim _{y_{t} \rightarrow \infty} \partial \phi^{I I I}\left(y_{t}\right) / \partial y_{t}=0$.

Figure 4 depicts the properties of $\phi^{I}\left(y_{t}\right), \phi^{I I}\left(y_{t}\right), \phi^{I I I}\left(y_{t}\right)$ over the interval $y_{t} \in[\widetilde{y}, \widehat{y}]$. It should be noted that while the function is smooth at $\tilde{y}$, (i.e., when pubic education is adopted) since existing resources are optimally reallocated between investments in human and physical capital, there is a kink at $\hat{y}$ (i.e., when workers start investing in physical capital) due to the fact that a larger fraction of income and the marginal propensity to save increases.

Corollary 4 Under A2-A5, output per worker $y_{t}$ increases monotonically in Stage II of Regime II and converges to a steady-state equilibrium $\bar{y}>\widehat{y}$.

Proof. Follows directly from the properties of $\phi^{I I I}\left(y_{t}\right)$.

Proposition 2 Under A2-A5, the economy converges to a steady-state equilibrium in which the income gap between the offspring of the Capitalists and the Workers is eliminated.

Proof. As follows from the properties of (9),(15),(30),(31) and Corollary 4, noting that $\lim _{y_{t} \rightarrow \infty} d \phi^{I I I}\left(y_{t}\right) / d y_{t}=$ 0 , the economy converges to a unique steady-state vector $(\bar{y}, \bar{k}, \bar{\tau}, \bar{h})$. Since

$$
b_{t+1}^{i}=\beta\left[w\left(k_{t+1}\right) h_{t+1}+\left(1-\tau_{t}\right) b_{t}^{i} R\left(k_{t+1}\right)-\theta\right] \quad \text { for } \quad t>\widehat{t}, \quad i=P . R
$$

where as follows from (14) $h_{t+1}=h\left(k_{t+1}\right)$ and $\tau_{t}=\tau\left(k_{t+1}\right)$ and therefore

$$
b_{t+1}^{i}=\zeta\left(b_{t}^{i}, k_{t+1}\right) .
$$


Hence, given $\bar{k}$ it follows that, in the steady state, $b^{i}=\bar{b}^{i}$ where $\bar{b}^{i}=\zeta\left(\bar{b}^{i}, \bar{k}\right)$, otherwise (since $\left.\partial \zeta\left(b^{i}, \bar{k}\right) / \partial b^{i} \geq 0\right)$ either $\left[b^{i}\right.$ decreases (increases) for all $i$ and thus $k$ decreases (increases)] or $\left[b^{R}\right.$ increases indefinitely and $b^{P}$ decreases to zero, and thus $k$ increases $]$ in contradiction to the stationarity of $\bar{k}$. Hence, $\bar{b}^{R}=\zeta\left(\bar{b}^{R}, \bar{k}\right), \bar{b}^{P}=\zeta\left(\bar{b}^{P}, \bar{k}\right)$, and $\bar{k}=\kappa\left(\bar{b}^{R}, \bar{b}^{P}\right)$. Since $\zeta\left(\bar{b}^{i}, \bar{k}\right)=$ $\beta\left[\bar{h} w(\bar{k})-\theta+(1-\bar{\tau}) R(\bar{k}) b_{t}^{i}\right]$, and since in Stage II of Regime II , $h(\bar{e}) w(\bar{k})-\theta>0$, it follows form the existence of $\bar{b}^{i}$, that $(1-\bar{\tau}) R(\bar{k})<1$ and therefore $\bar{b}^{i}$ is unique for all $i ; \bar{b}^{i}=\beta[\bar{h} w(\bar{k})-\theta] /[1-$ $\beta(1-\bar{\tau}) R(\bar{k})]$.

The growth of income per capita in the two stages of Regime II is an outcome of physical and human capital accumulation. Moreover, the capital-labor ratio increases, and hence, as observed historically, the wage-rental ratio increases as well. ${ }^{49}$

In Stage II of Regime II the economy witnesses the demise of the class society. The descendents of Workers as well as Capitalists acquire human capital as well as physical capital, the income gap between the classes narrows and vanishes in the long-run, and class characteristics fade.

\subsection{Analysis}

In Regime I, physical capital is scarce, the contribution of human capital to the production process does not justify investment in human capital, and the process of development is fueled by capital accumulation. The wage rate is lower than the critical level that would enable individuals who do not own any capital to engage in intergenerational transfers (and thus savings). Workers, therefore, consume their entire wages; they are not engaged in saving, capital accumulation, and intergenerational transfers. Their descendents, therefore, are also unable to engage in saving and intergenerational transfers and Workers are in a temporary steady-state equilibrium in which there is no investment in either physical or human capital. In contrast, the income of the Capitalists, who own the entire stock of capital in the economy, is sufficiently high, permitting intergenerational transfers and capital accumulation. Intergenerational transfers among the Capitalists increase over time and the stock of physical capital in the economy, therefore, increases as well. During this regime, physical capital accumulation by the Capitalists decreases the return to physical capital and the importance of potential human capital formation in sustaining the return to capital increases. However, as long as the Capitalists generate a higher rate of return from a direct investment in physical capital, rather than from supporting the education of Workers, which would complement

\footnotetext{
${ }^{49}$ The rise in $k$, despite the accumulation of human capital is a result of the concavity of the human capital production function. Suppose not. If $k$ would decline over time, the return to capital would rise and the return to education would decline, bringing about a reduction in investment in education and a rise in investment in physical capital and thus an increase in $k$, in contradiction to the assumed reduction in $k$.
} 
their capital in the production process, the qualitative structure of the economy remains unchanged. The Workers remains in a poverty trap, the Capitalists get richer, and the process of development is based solely on physical capital accumulation.

The accumulation of physical capital by the Capitalists in Regime I gradually raises the potential role of the education of the Workers in sustaining the profit rates of the Capitalists. Ultimately, the Capitalists find it beneficial to support public education, and the economy enters Regime II where the process of development is fueled by human as well as physical capital accumulation.

Regime II is subdivided into two stages. In Stage I of Regime II, the economy witnesses the birth of public education. The Capitalists invest in physical capital, and workers, as well as the Capitalists acquire education financed by the Capitalists. The wage income, however, is not high enough to permit physical capital accumulation by the Workers. During Stage I of Regime II, the accumulation of physical and human capital increases wage income further, and ultimately the economy enters Stage II of Regime II in which the wage income is high enough to permit the accumulation of physical capital by the Workers.

In Stage II of Regime II the economy witnesses the demise of the class society. The descendents of Workers as well as Capitalists acquire human capital as well as physical capital, the income gap between the classes narrows, vanishing in the long-run, and class characteristics fade.

\section{Evidence from the Balfour Act - UK 1902}

The basic premise of this research, regarding the positive attitude of the capitalists towards education reforms, is examined based on the voting patterns on the Balfour Act of 1902 - the proposed education reform in the UK that marked the consolidation of a national education system and the creation of a publicly supported secondary school system. Although the formal model abstracts from heterogeneity in the degree of complementarity between human and physical capital in dif-

ferent industries and thus does not permit for a conflict of interests among capitalists about the timing of education reforms, the theory implies that variations in the degree of complementarity between human capital and physical capital and land in various industries would induce variations in the level of support for education reforms among capitalists and landowners. In particular, variations in the support of MPs for the Balfour Act would reflect the variations in the skill intensity in the counties they represent. Higher support for the Balfour Act would be expected from MPs who represent industrial skill-intensive counties.

We construct a data set gathered from a variety of historical sources on the third (and final) 
vote on the Balfour act. ${ }^{50}$ The data, as described in detail in the Appendix, combines the home district and party affiliation for each MP with his voting record on the Balfour Act. In addition, the data includes county level data on the percentage of employment in skill-intensive industries, income per capita, degree of urbanization, and religious affiliation.

As is apparent from Table 1, which summarizes the voting patterns on the Balfour Act according to party affiliation, Conservatives and Unionists were predominantly supportive of the Balfour Act while Liberals were predominantly opposed. Nevertheless, variations in the voting patterns within each of the parties due to a significant number of abstentions, is sufficient for a significant identification.

We perform Ordered Probit regressions to examine the effect of the percentage of employment in industrial skill-intensive sectors in each MP's county on the voting patterns on the Balfour Act. As documented in Table 2, there exists a significant positive effect of the percentage of employment in industrial skill-intensive sectors in a county on the propensity of their MPs to vote in favor of the education reform proposed by the Balfour Act of 1902 .

Regression (1) in Table 2 examines the effect of the employment in industrial skill-intensive sectors in each MP's county on the voting patterns on the Balfour Act, controlling for county's per-capita income. Consistent with the main hypothesis of this research, the regression shows a significant positive effect of the ratio of employment in industrial skill-intensive sectors in each MP's county on the propensity to vote for the proposed education reform.

The proposed Balfour Act of 1902 provided a role for the Anglican Church in the provision of education. As a result the non-conformists objected to the Act. In Regression (2), therefore, we control for the percentage of non-conformists in each county. The regression indeed shows a significant negative effect of the fraction of non-conformists in the county on the support for the Act by the MPs representing that county. Nevertheless, the effect of the ratio of employment in industrial skill-intensive sectors on the vote remains significantly positive.

In Regression (3) we add dummy variables to control for counties in Scotland and Wales. Scotland and Wales tended to view themselves as independent nations within the UK. This may have led them to vote systematically for or against certain measures based solely on nationalistic grounds (e.g., being against universal education because it imposes "English" education). Since counties in Scotland and Wales were characterized by lower income, a higher fraction of Catholics, a

\footnotetext{
${ }^{50} \mathrm{In}$ previous education acts, the third and final vote was conducted by voice, and no record exists of the distribution of votes across MPs. Some records of votes on various amendments for these education bills do exist, but it is not possible to specify clearly which of the votes were crucial, or whether an affirmative vote is actually in support of the ultimate education bill.
} 
smaller urban sector, and a smaller skill-intensive industrial sector, relative to England, excluding these controls might cause omitted variable biases in the other coefficient estimates. However, despite the incorporation of the Scotland and Wales dummies, the effect of the ratio of employment in industrial skill-intensive sectors on the vote remains significantly positive.

In Regression (4) we control for party affiliation. As is apparent from Table 1, there is a strong correlation between party affiliation and voting patterns: Conservatives and Unionists were predominantly supportive of the Balfour Act while Liberals were predominantly opposed. Indeed, the regression shows that affiliation with the Liberal party has a highly significant negative effect on the support for the Balfour Act, and affiliation with the Conservative party therefore has a highly significant positive effect on the support for the Act. Nevertheless, the effect of the ratio of employment in industrial skill-intensive sectors on the vote remains significantly positive. Further, as established in Table 3, the ratio of employment in industrial skill-intensive sectors has a significantly positive effect on the support for the Conservative party, which, in turn, supports the education act.

Finally, in Regression (5) of Table 2, we control for the percentage of the urban population within each county. This is an attempt to separate between demand for education that stems from skill-intensive industrial development, and other sources of demand for education in an urban environment. In particular, support for public education may reflect the desire to reduce crime, which is prevalent in an urban environment. ${ }^{51}$. Interestingly, urbanization has no significant effect on the support for the education act and the effect of the weight of the skill-intensive industrial sector remains significantly positive.

Table 3 reports the results of probit regressions of the effect of the ratio of employment in the skill-intensive industrial sector in each MP's county on party affiliation, controlling for the percentage of employment in skill-intensive industries, per-capita income, degree of urbanization, and religious affiliation in each county, and incorporating the Scotland and Wales dummies. It shows that the ratio of employment in the skill-intensive industrial sector in each MP's county has a significant positive effect on affiliation with the Conservative party. ${ }^{52}$

Hence, it is apparent from Tables 2 and 3 that the ratio of employment in the skill-intensive industrial sector has a significant positive impact on the vote on the Balfour Act through two channels. The first is the direct channel, holding party constant. The second is through its

\footnotetext{
${ }^{51}$ Unfortunately, direct crime statistics at the county level are unavailable for this period.

${ }^{52}$ Adjusting the probit results to obtain marginal effects, we find that a one percentage point increase in the ratio of employment in the industrial sector raises the probability of belonging to the Liberal party by approximately 1.7 percentage points.
} 
influence on the MP's party itself. ${ }^{53}$

\section{Concluding Remarks}

We argue that capital accumulation in the process of industrialization gradually intensified the relative scarcity of skilled labor and generated an incentive for human capital accumulation. Due to the complementarity between physical and human capital in production, the capitalists were among the prime beneficiaries of the accumulation of human capital by the masses. They therefore had the incentive to support the provision of public education that improved their economic wellbeing, contributing significantly to the demise of the existing class structure. Thus, in contrast to the conventional wisdom, the theory suggests that the demise of the capitalists-workers class structure was affected significantly by the outcome of a productive cooperation between capitalists and workers, rather than an outcome of a divisive class struggle. The basic premise of this research, regarding the positive attitude of capitalists towards education reforms, is supported empirically by a newly constructed data set on the voting patterns on England's education reform proposed in the Balfour Act of 1902.

The political reforms that accompanied the education reforms in Europe during the 19th century, may be viewed as either an attempt by the capitalists to broaden the coalition that supports vocational public education, against the wishes of the clergy and the landlords for whom human capital was less complementary in production, ${ }^{54}$ or as a by-product of the educational reforms that made political inequality harder to sustain or justify. One may argue that political reforms during the 19th century shifted the balance of power towards the working class and enabled workers to implement education reforms against the will of the capitalists. The evidence, however, does not support this alternative hypothesis. Education reforms took place in autocratic states that did not relinquish political power throughout the 19th century, and major reforms occurred in societies in the midst of the process of democratization well before the stage in which the working class constituted the majority among the voters.

\footnotetext{
${ }^{53}$ It should be noted that the voting patterns of the industrial-intensive counties on alternative bills in the same year differed significantly. In particular, the share of employment in the industrial sector is an insignificant explanatory variable for the 1902 vote on an income tax bill using an ordered probit with the same set of controls. This result suggests that representatives from industrial-intensive counties do not vote uniformly on each bill.

${ }^{54}$ Cultural differences across societies may have resulted in the failure of some societies to adopt efficient institutions (e.g., Greif (1994)). Therefore, the timing of education reforms relative to the process of development may differ across countries.
} 


\section{Data Appendix}

Vote on the Balfour Act - The voting record of each MP on the Balfour Act is gathered from the supplement to the British Parliamentary Papers, the Division Lists. The record specifies who voted in favor of and who voted against the bill. ${ }^{55}$ The list of the names and home districts of each of the British MPs during the vote on the Balfour Act is collected from The British Parliamentary Papers. Party affiliation for each MP during the vote on the Balfour Act is taken from Who's Who of British Parliament. ${ }^{56}$

Income per capita - Income per capita in each county is estimated for each county using income tax data. Source: Hechter (2001).

Percent in skill-intensive occupations - the proportion of the population in a county that is employed in skill-intensive industrial occupations. Sources: British Regional Employment Statistics, 1901, Lee (1979) and Hechter (2001). ${ }^{57}$ Based on the British Regional Employment Statistics, 1901, Hechter divides the total employment in each county into four categories: Agricultural, Manufacturing, Middle Class, and Civil Servant. The Middle Class category consists of skill-intensive manufacturing occupations (Mechanical Engineering, Instrument Engineering, Electrical Engineering, Distributive Trades, Insurance/Banking/Finance, Professional and Scientific, and Miscellaneous). Employment in theses occupations is used in the regression to capture the percentage of employment in skill-intensive occupations.

Percent non-conformists - the proportion of the population in a county that is non-conformists. Source: Hechter (2001).

Percent urban - the proportion of the population in a county that resides in urban areas. Source: Hechter (2001).

\footnotetext{
${ }^{55}$ Any member not listed abstained. Of the 562 MPs, 226 abstained.

${ }^{56}$ We used only those MPs in either the Liberal or Conservative parties, the dominant parties of the time. The only other party of significance was the Unionist party, but membership in this party was not mutually exclusive with the other two. Many members of the Liberal and Conservative parties were Unionists as well. In addition, there are a number of Unionist-only members. Excluding pure Unionists and other members of smaller parties, we remove 101 MPs from the sample. In addition, we were unable to locate party affiliation data on six of the MPs, and removed them from the sample.

${ }^{57}$ The British Regional Employment Statistics provides a breakdown of employment by industry in each county in the UK, an area that encompasses several districts. Unfortunately, the employment data is not at a district level and each MP was therefore assigned the percentage appropriate to the county within which his district existed.
} 


\section{References}

[1] ABRAMOVITZ, M. (1993), "The Search of the Sources of Growth: Areas of Ignorance, Old and New", Journal of Economic history, 53, 217-243.

[2] ABRAMOVITZ, M. and DAVID, P.A. (2000), "American Macroeconomic Growth in the Era of knowledge-Based Progress: The Long-Run Perspective", ENGERMAN, S.L. and GALLMAN, R.E. (eds.), The Cambridge Economic History of the United States (Cambridge; New York NY: Cambridge University Press).

[3] ACEMOGLU, D. (1998), "Why Do New Technologies Complement Skills? Directed Technical Change and Wage Inequality", Quarterly Journal of Economics, 113, 1055-1089.

[4] ACEMoglu, D. and ROBInSON, J. A. (2000), "Why Did the West Extend the Franchise? Democracy, Inequality and Growth in Historical Perspective", Quarterly Journal of Economics, 115, 1167-1199.

[5] ALTONJI, J. G., HAYASHI, F. and KOTLIKOFF, L. J. (1997), "Parental Altruism and Inter Vivos Transfers: Theory and Evidence", Journal of Political Economy, 105, 1121- 1166.

[6] ANDERSON, R. D. (1975), Education in France 1848-1870. (Oxford: Clarendon Press).

[7] BENABOU, R. (1996), "Inequality and Growth", NBER Macroeconomics Annual, 11, 11-74.

[8] BENABOU, R. (2000), "Unequal Societies: Income Distribution and the Social Contract", American Economic Review, 90, 96-129.

[9] BENABOU, R. (2002), "Tax and Education Policy in a Heterogeneous-Agent Economy: What levels of Redistribution Maximize Growth and Efficiency?", Econometrica, 70, 481-517.

[10] BERGHAHN, V. R. (1994): Imperial Germany, 1871-1914, Economy, Society, Culture and Politics (Providence: Berghahn Books).

[11] BERTOCCHI, G., and SPAGAT, M. (2004), "The Evolution of Modern Educational Systems: Technical Vs. General Education, Distributional Conflict and Growth," Journal of Development Economics, 73, 559-582.

[12] BOURGuignON, F. and VERDIER, T. (2000), "Oligarchy, Democracy, Inequality and Growth", Journal of Development Economics, 62, 285-313.

[13] BOWEN, J. (1981), A History of Western Education. Vol. 3: The Modern West Europe and the New World (New York: St. Martin's Press).

[14] BOWLES, S., and GINTIS, H. (1975), "Capitalism and Education in the United States", Socialist Revolution, 5, 101-138.

[15] CABALlE, J., and SANTOS, M. (1993), "On Endogenous Growth with Physical and Human Capital", Journal of Political Economy, 101, 1042-1067.

[16] CAMERON, R. (1989), A Concise Economic History of the World from Paleolithic Times to the Present (Oxford: Oxford University Press).

[17] CASELLI, F. (1999), "Technological Revolutions", American Economic Review, 89, 78-102.

[18] CIPOLLA, C. M. (1969), Literacy and Development in the West (Harmondsworth: Penguin Books).

[19] CLARK, G. (2003), "The Condition of the Working-Class in England, 1200-2000: Magna Carta to Tony Blair", UC Davis. 
[20] CLARK, G. (2002), "Farmland Rental Values and Agrarian History: England and Wales, 1500-1912," European Review of Economic History, 6, 281-309.

[21] CRAIG, F. W. S. (1989), British Electoral Facts, 1832-1987 (Brookfield: Gower Press).

[22] CRESSY, D. (1980) Literacy and the Social Order: Reading and Writing in Tudor and Stuart England (Cambridge: Cambridge University Press).

[23] CUBBERLY, E. P. (1920), The History of Education (Cambridge: Cambridge University Press).

[24] DOEPKE, M. and ZILIBOTTI, F. (2005), "The Macroeconomics of Child Labor Regulation", American Economic Review, forthcoming.

[25] DURLAUF, S. N. (1996), "A Theory of Persistent Income Inequality", Journal of Economic Growth, 1, 75-94.

[26] DYNAN, K.E., SKINNER, J. and ZELDES, S. (2004), "Do the Rich Save More?" Journal of Political Economy, 112, 397-444.

[27] ENGERMAN, S. and SOKOLOFF, K. L. (2000), "Factor Endowment, Inequality, and Paths of Development among New World Economies," UCLA.

[28] FERNANDEZ, R. and ROGERSON, R. (1996), "Income Distribution, Communities, and the Quality of Public Education", Quarterly Journal of Economics, 111, 135-164.

[29] FIELD, A. (1976), "Educational Reform and Manufacturing Development in Mid-Nineteenth Century Massachusetts", Journal of Economic History, 36, 263-266.

[30] FEINSTEIN, C. (1988), "The Rise and Fall of the Williamson Curve", Journal of Economic History 48, 699-729.

[31] FLORA, P., KRAUS, F. and PFENNING, W. (1983), State, Economy and Society in Western Europe 1815-1975, Vol. I. (Chicago: St. James Press).

[32] GALOR, O. and ZEIRA, J. (1993), "Income Distribution and Macroeconomics", Review of Economic Studies, 60, 35-52.

[33] GALOR, O. and TSIDDON, D. (1997), "Technological Progress, Mobility, and Growth", American Economic Review, 87, 363-82.

[34] GALOR, O. and MOAV, O. (2000), "Ability Biased Technological Transition, Wage Inequality and Growth", Quarterly Journal of Economics, 115, 469-498.

[35] GALOR, O. and MOAV, O. (2004) "From Physical to Human Capital: Inequality in the Process of Development", Review of Economic Studies, 71, 1001-1026.

[36] GALOR, O., MOAV, O. and VOLRATH, D. (2003), "Land Inequality and the Emergence of Human Capital Promoting Institutions" Brown University.

[37] GOLDIN, C. (1999), "Egalitarianism and the Returns to Education During the Great Transformation of American Education", Journal of Political Economy, 107, S65-S94.

[38] GOLDIN, C. and KATZ, L.F. (1998), "The Origins of Technology-Skill Complementary", Quarterly Journal of Economics, 113, 693-732.

[39] GOLDIN, C. and KATZ, L.F. (2001), "The Legacy of U.S. Educational Leadership: Notes on Distribution and Economic Growth in the 20th Century", American Economic Review, 91, $18-23$. 
[40] GRAFF H. J. (1987), The labyrinths of literacy: reflections on literacy past and present. (London: Falmer Press).

[41] GREEN, A. (1990), Education and State Formation (New York: St. Martin's Press).

[42] GREIF, A. (1994), "Cultural Beliefs and the Organization of Society - A Historical and Theoretical Reflection on Collectivist and Individualist Societies", Journal of Political Economy, 102, 912-950.

[43] GROSSMAN, H. I. (1994), "Production, Appropriation, and Land-Reform", American Economic Review, 84, 705-712.

[44] GROSSMAN, H. I. and Kim, M. (1999), "Education Policy: Egalitarian or Elitist?" Brown University.

[45] HASSLER, J. and RODRIGUEZ MORA, J. (2000), "Intelligence, Social Mobility, and Growth", American Economic Review, 90, 888-908.

[46] HECHTER, M. (2001), Internal Colonialism Study: National Integration in the British Isles, 1851-1966 (Ann Arbor: Inter-University Consortium for Political and Social Research).

[47] HURT, J. (1971), Education in Evolution (London: Paladin).

[48] KALDOR, N. (1957), "A Model of Economic Growth", Economic Journal, 67, 591-624.

[49] KATZ, L. F. and MURPHY, K. M. (1992), "Changes in Relative Wages 1963-1987: Supply and Demand Factors", Quarterly Journal of Economics, 107, 35-78.

[50] KIRBY, P. (2003), Child Labor in Britain, 1750-1870 (Basingstoke: Palgrave-MacMillan).

[51] KOSSMAN E. H. (1978), The Low Countries 1780-1940 (Oxford: Clarendon Press).

[52] KURIAN, G. T. (1994), Datapedia of the U.S. 1790-2000, America Year by Year. (Lonham, MD: Bernan Press).

[53] KEYNES, J.M. (1920), "The Economic Consequences of the Peace" (London: Macmillan and Co. Limited).

[54] LANDES, D. S. (1969), The Unbound Prometheus. Technological Change and Industrial Development in Western Europe from 1750 to the Present (Cambridge: Cambridge University Press.)

[55] LEE, C. (1979), British Regional Employment Statistics,1841-1971 (Cambridge: Cambridge University Press).

[56] LEVY-LEBOYER, M., and BOURGUIGNON, F. (1990), The French Economy in the Nineteenth Century (Cambridge: Cambridge University Press).

[57] LEWIS, W.A. (1954), "Economic Development with Unlimited supply of Labor", The Manchester School, 22, 139-91.

[58] LINDERT, P. H., and WILLIAMSON, J. G. (1976), "Three Centuries of American Inequality", Research in Economic History, 1, 69-123.

[59] LIZZERI, A and PERSICO, N. (2004), "Why Did the Elites Extend the Suffrage? Democracy and the Scope of Government, With an Application to Britain's Age of Reform", Quarterly Journal of Economics, 119, 707 - 765.

[60] MAllinson, V. (1963), Power 6 Politics in Belgian Education 1815 to 1961 (London: Heinemann Educational Books). 
[61] MAOZ, Y.D. and MOAV, O. (1999), "Intergenerational Mobility and the Process of Development", Economic Journal, 109, 677-97.

[62] MATTHEWS, R.C., FEINSTEIN, C.H. and ODLING-SMEE, J.C. (1982), British Economic Growth 1856-1973 (Stanford: Stanford University Press).

[63] McClELLAND, C. E. (1980), State, Society, and University in Germany: 1700-1914 (Cambridge: Cambridge University Press).

[64] MENCHIK, P. and DAVID, M. (1983), "Income Distribution, Lifetime Savings, and Bequests", American Economic Review, 73, 672-690.

[65] MITCH, D. (1992), The Rise of Popular Literacy in Victorian England: the Influence of Private Choice and Public Policy (Philadelphia: University of Pennsylvania Press).

[66] MITCH, D. (1993), "The Role of Human Capital in the First Industrial Revolution," Mokyr, J. (ed.) The British Industrial Revolution: An Economic Perspective (Boulder: Westview Press) 267-307.

[67] MOKYR, J. (1990) The Lever of Riches (New York: Oxford University Press).

[68] MOKYR, J. (1993), "The New Economic History and the Industrial Revolution", Mokyr, J. (ed.), The British Industrial Revolution: an Economic Perspective (Boulder Colorado: Westview Press), 1-131.

[69] MOKYR, J. (2001), "The Rise and Fall of the Factory System: Technology, Firms, and Households since the Industrial Revolution, Carnegie-Rochester Conference Series On Public Policy, 55, 1-45.

[70] MOKYR, J. (2002), The Gifts of Athena: Historical Origins of the Knowledge Economy (Princeton: Princeton University Press).

[71] MORRISSON, C. and SNYDER, W. (2000), "Income Inequalities in France from the Early Eighteenth Century to 1985", Revue Economique, 51, 119-154.

[72] MULLER, D. K. (1987), "The Process of Systematization: the Case of German Secondary Education", MULLER, D. K., RINGER, F. and SIMON, B. (eds.), The Rise of the Modern Educational System (Cambridge: Cambridge University Press).

[73] MUlligAN, C. B. and SALA-I-MARTIN, X. (1993), "Transitional Dynamics in Two Sector Models of Endogenous Growth", Quarterly Journal of Economics, 108, 739-773.

[74] O'ROURKE, K. H., TAYLOR, A. M. and WILliAmSON, J. G. (1996), "Factor Price Convergence in the Late Nineteenth Century", International Economic Review, 37, 499-530.

[75] RINGER, F. (1979), Education and Society in Modern Europe (Bloomington: Indiana University Press).

[76] SANDBERG, L. G. (1979), "The Case of the Impoverished Sophisticate: Human Capital and Swedish Economic Growth before World War I", The Journal of Economic History, 39, $225-241$.

[77] SANDERSON, M. (1995), Education, Economic Change and Society in England 1780-1870 (Cambridge: Cambridge University Press).

[78] SCHLEUNES, K. A. (1989), Schooling and Society: The politics of Education in Prussia and Bavaria 1750-1900 (Providence: Berg Publishers).

[79] SCOTT, F. D. (1977), Sweden: The Nation's History (Minneapolis: University of Minnesota Press). 
[80] SIMON, B. (1987), "Systematization and Segmentation in Education: the Case of England" MULLER, D. K., RINGER, F. and SIMON, B.(eds.), The Rise of the Modern Educational System (Cambridge: Cambridge University Press).

[81] SMELSER, N. (1991), Social Paralysis and Social Change: British Working-Class Education in the Nineteenth Century (Berkeley: University of California Press).

[82] SPREE, R. (1977), Die Wachstumszyklen der deutschen Wirtschaft von 1840 bis 1880 (Berlin: Dunker \& Humboldt).

[83] TAYLOR, A. M. (1999), "Sources of Convergence in the Late Nineteenth Century", European Economic Review, 43, 1621-1645.

[84] THOMPSON, E.P. (1968), The Making of the English Working Class (London: Penguin).

[85] TIPTON, F. B. (2003), A History of Modern Germany since 1815, (Berkeley: University of California Press)

[86] TOMES, N. (1981), "The Family, Inheritance and the Intergenerational Transmission of Inequality", Journal of Political Economy, 89, 928-958.

[87] WIENER, M. J. (1981), English Culture and the Decline of the Industrial Spirit, 1850-1980 (Cambridge: Cambridge University Press).

[88] WILliAmSON, J. G. (1985), Did British Capitalism Breed Inequality? (Boston: Allen \& Unwin).

[89] WOLTHUIS, J. (1999), Lower Technical Education in the Netherlands 1798-1993: the Rise and Fall of a Subsystem (http://www.ub.rug.nl/eldoc/dis/ppsw/j.wolthuis/titlecon.pdf.). 
Table 1. Voting patterns according to party affiliation and the regional distribution of party affiliation

\begin{tabular}{|l|l|l|l|l|}
\hline & Yes & No & Abstain & Total \\
\hline Liberal & 19 & 98 & 92 & 209 \\
\hline Conservative & 155 & 3 & 94 & 252 \\
\hline Unionist & 43 & 0 & 26 & 69 \\
\hline Other & 4 & 14 & 14 & 32 \\
\hline Total & 221 & 115 & 226 & 562 \\
\hline
\end{tabular}

\begin{tabular}{|l|l|l|l|l|}
\hline & Scotland & Wales & England & Total \\
\hline Liberal & 46 & 20 & 143 & 209 \\
\hline Conservative & 18 & 2 & 232 & 252 \\
\hline Unionist & 6 & 1 & 62 & 69 \\
\hline Other & 2 & 7 & 23 & 32 \\
\hline Total & 72 & 30 & 460 & 562 \\
\hline
\end{tabular}


Table 2. The effect of the weight of the skill-intensive sector on the support for the Balfour Act

\begin{tabular}{|c|c|c|c|c|c|}
\hline Exp Variable & $\begin{array}{c}\text { (1) } \\
\text { Vote on } \\
\text { Balfour Act }\end{array}$ & $\begin{array}{c}\text { (2) } \\
\text { Vote on } \\
\text { Balfour Act }\end{array}$ & $\begin{array}{c}\text { (3) } \\
\text { Vote on } \\
\text { Balfour Act }\end{array}$ & $\begin{array}{c}(4) \\
\text { Vote on } \\
\text { Balfour Act }\end{array}$ & $\begin{array}{c}(5) \\
\text { Vote on } \\
\text { Balfour Act }\end{array}$ \\
\hline Income per capita & $\begin{array}{r}-0.0011 \\
(0.12)\end{array}$ & $\begin{array}{r}-0.0030 \\
(0.33)\end{array}$ & $\begin{array}{r}-0.0033 \\
(0.36)\end{array}$ & $\begin{array}{r}-0.0118 \\
(1.33)\end{array}$ & $\begin{array}{r}-0.0120 \\
(1.33)\end{array}$ \\
\hline $\begin{array}{l}\% \text { in skill-intensive } \\
\text { occupations }\end{array}$ & $\begin{array}{l}5.7298 \text { ** } \\
(4.49)\end{array}$ & $\begin{array}{l}4.1818 \text { ** } \\
(3.09)\end{array}$ & $\begin{array}{l}4.2554 \text { ** } \\
(3.20)\end{array}$ & $\begin{array}{c}2.6177^{*} \\
(1.93)\end{array}$ & $\begin{array}{c}2.6171^{*} \\
(1.94)\end{array}$ \\
\hline$\%$ non-conformists & & $\begin{array}{l}-1.9109 * * \\
(3.95)\end{array}$ & $\begin{array}{r}-1.4129 \\
(1.59)\end{array}$ & $\begin{array}{r}0.7349 \\
(0.67)\end{array}$ & $\begin{array}{r}0.7395 \\
(0.67)\end{array}$ \\
\hline Scotland dummy & & & $\begin{array}{r}0.0215 \\
(0.09)\end{array}$ & $\begin{array}{r}-0.1246 \\
(0.50)\end{array}$ & $\begin{array}{r}-0.1216 \\
(0.46)\end{array}$ \\
\hline Wales dummy & & & $\begin{array}{c}-0.7289 * * \\
(2.01)\end{array}$ & $\begin{array}{c}-0.9086 \text { ** } \\
(2.01)\end{array}$ & $\begin{array}{l}-0.9057^{* *} \\
(1.99)\end{array}$ \\
\hline Party affiliation & & & & $\begin{array}{l}-1.7404^{* *} \\
(11.44)\end{array}$ & $\begin{array}{l}-1.7399 * * \\
(11.46)\end{array}$ \\
\hline$\%$ urban & & & & & $\begin{array}{r}0.0246 \\
(0.10)\end{array}$ \\
\hline Chi-square p-val & 0.0000 & 0.0000 & 0.0000 & 0.0000 & 0.0000 \\
\hline Total observations & 455 & 455 & 455 & 455 & 455 \\
\hline Method & Oprobit & Oprobit & Oprobit & Oprobit & Oprobit \\
\hline
\end{tabular}

Absolute values of t-ratios are given in parentheses

** indicates significance at $5 \%$

* indicates significance at $10 \%$

Vote on Balfour: 2=Yes, $1=$ Abstain, $0=$ No

Party Affiliation: $1=$ Liberal, $0=$ Conservative

Standard errors are adjusted by clustering by county 
Table 3. The effect of the weight of the skill-intensive sector on MP's party affiliation

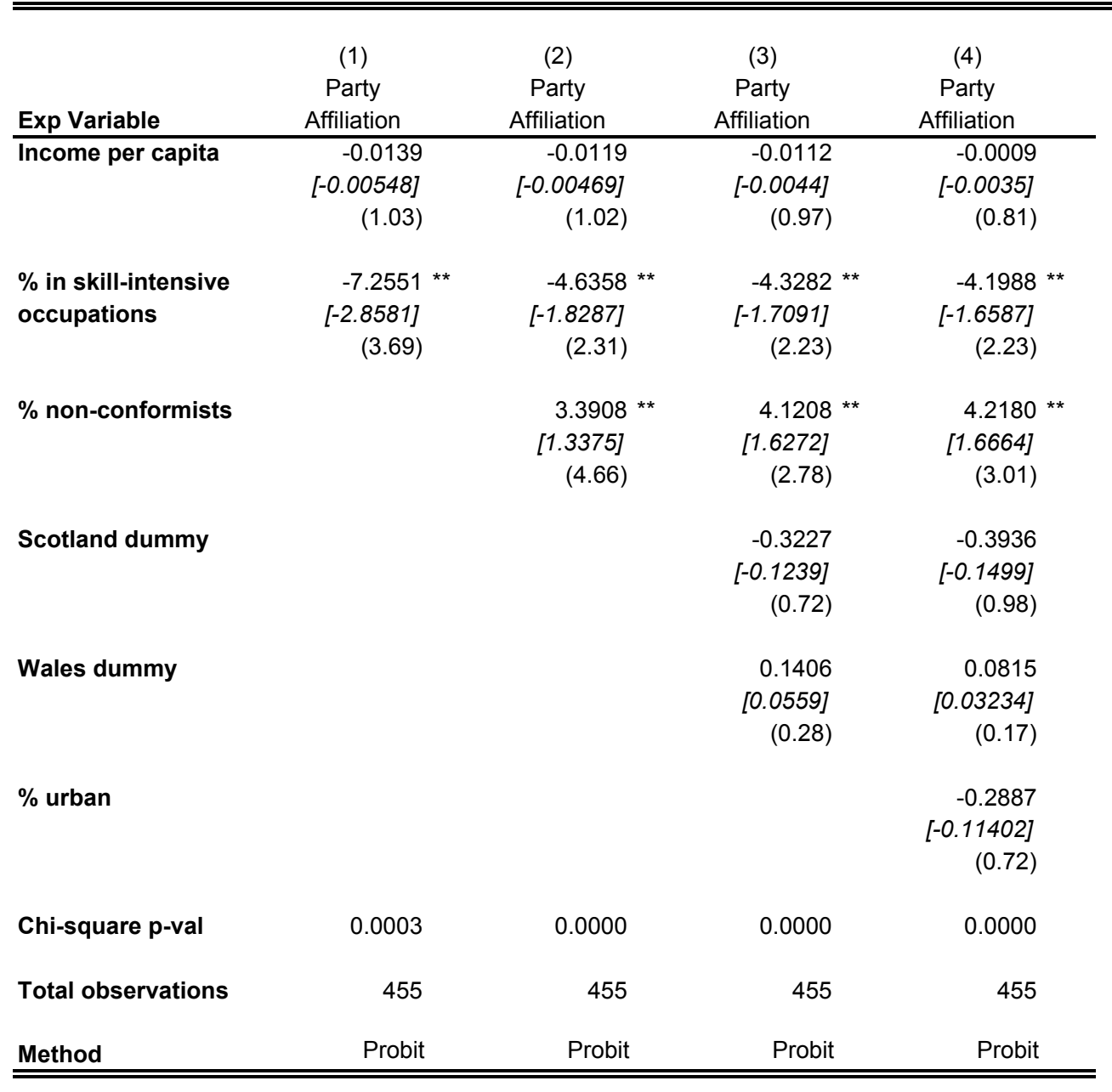

Absolute values of t-ratios are given in parentheses

** indicates significance at $5 \%$

* indicates significance at $10 \%$

Marginal effects are reported in square brackets

Vote on Balfour: $2=$ Yes, $1=$ Abstain, $0=$ No

Party affiliation: $1=$ Liberal, $0=$ Conservative

Standard errors are adjusted by clustering by county 
Figure 1. Schooling, Factor Prices and Inequality England 1770-1920

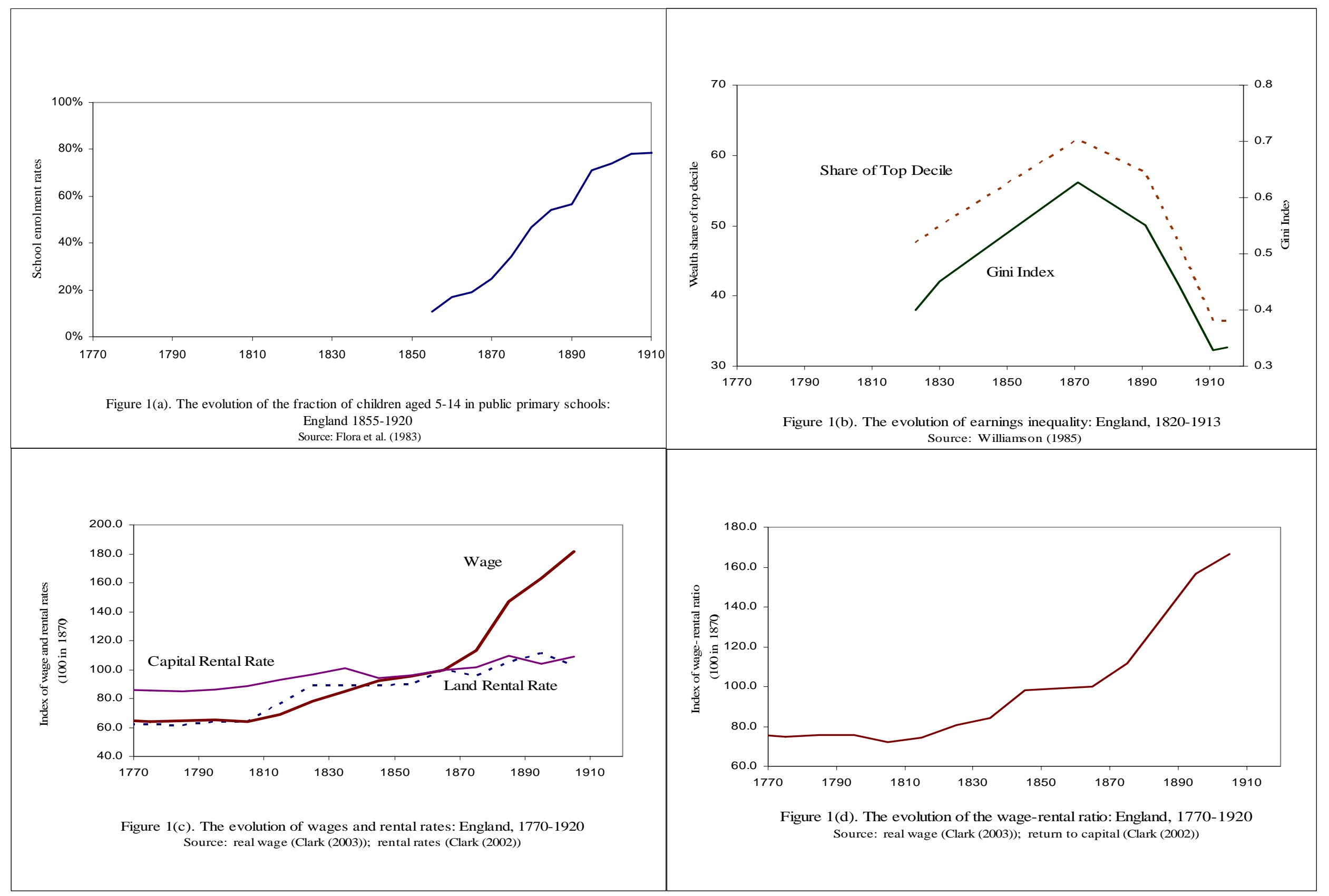


Figure 2. Schooling, Factor Prices and Inequality

France 1770-1930

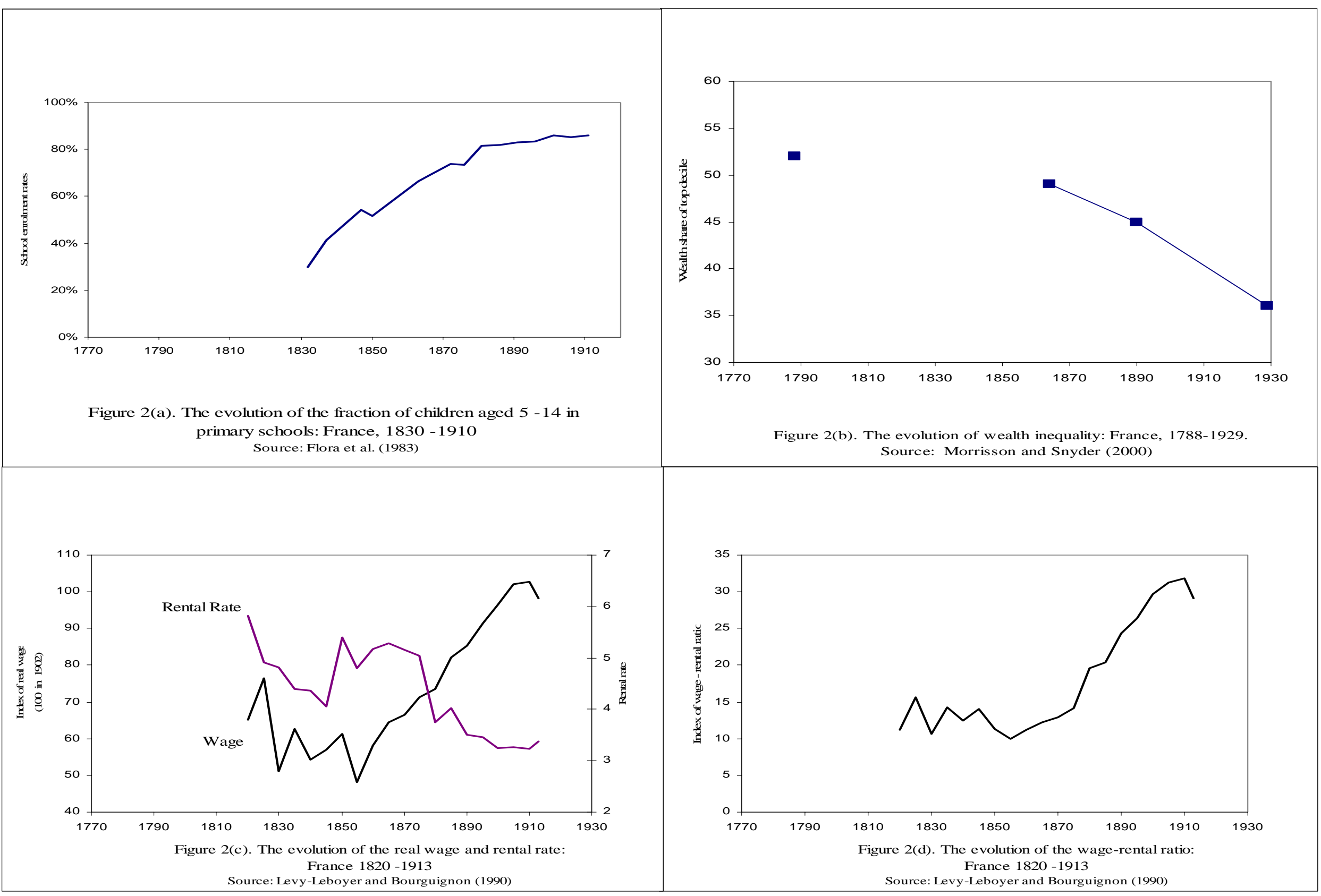




\section{Figure 3. The Evolution of Voting Rights and School Enrolment}

England and France 1820-1925

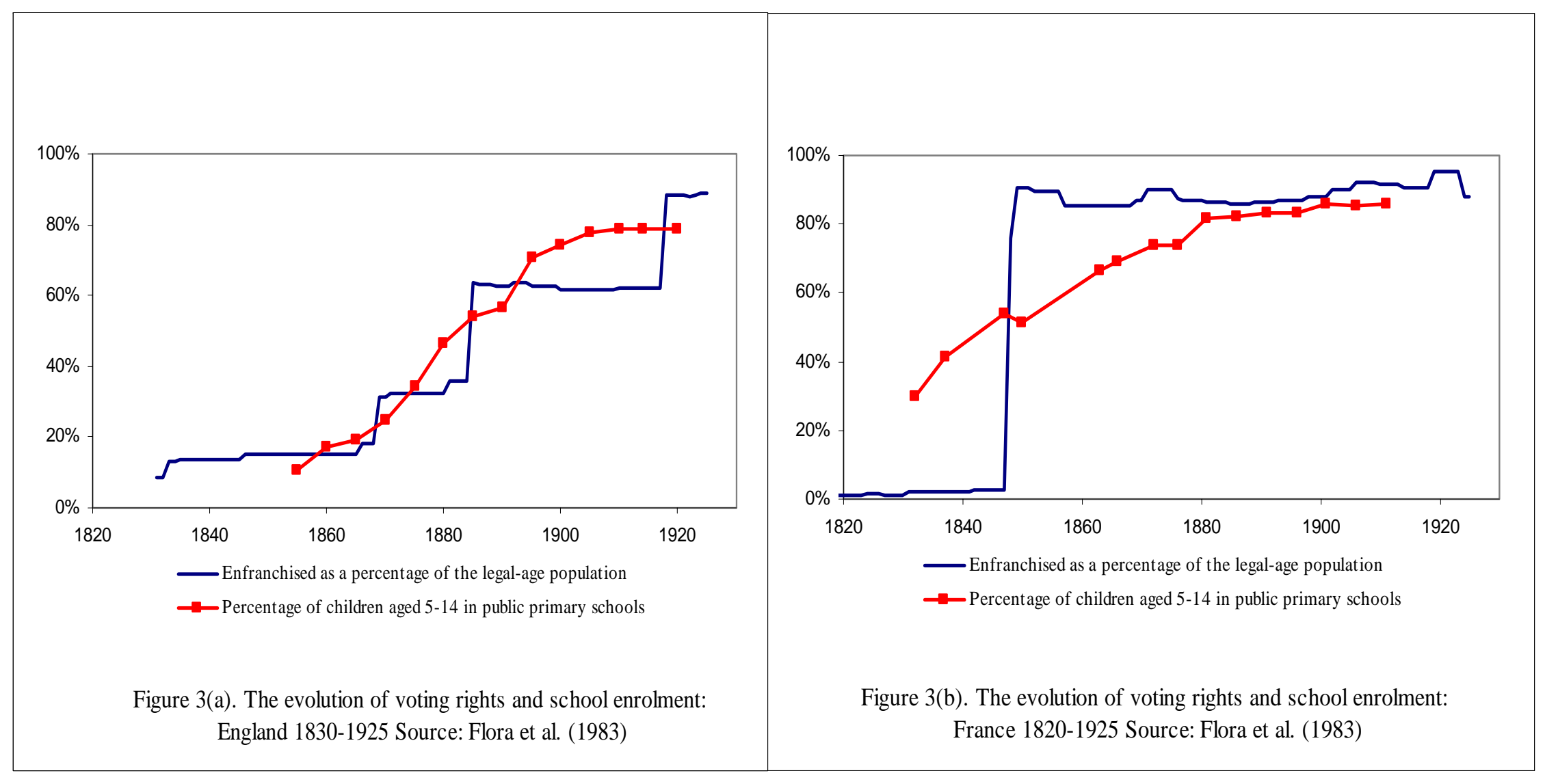


Figure 4. The evolution of output per worker in the process of development

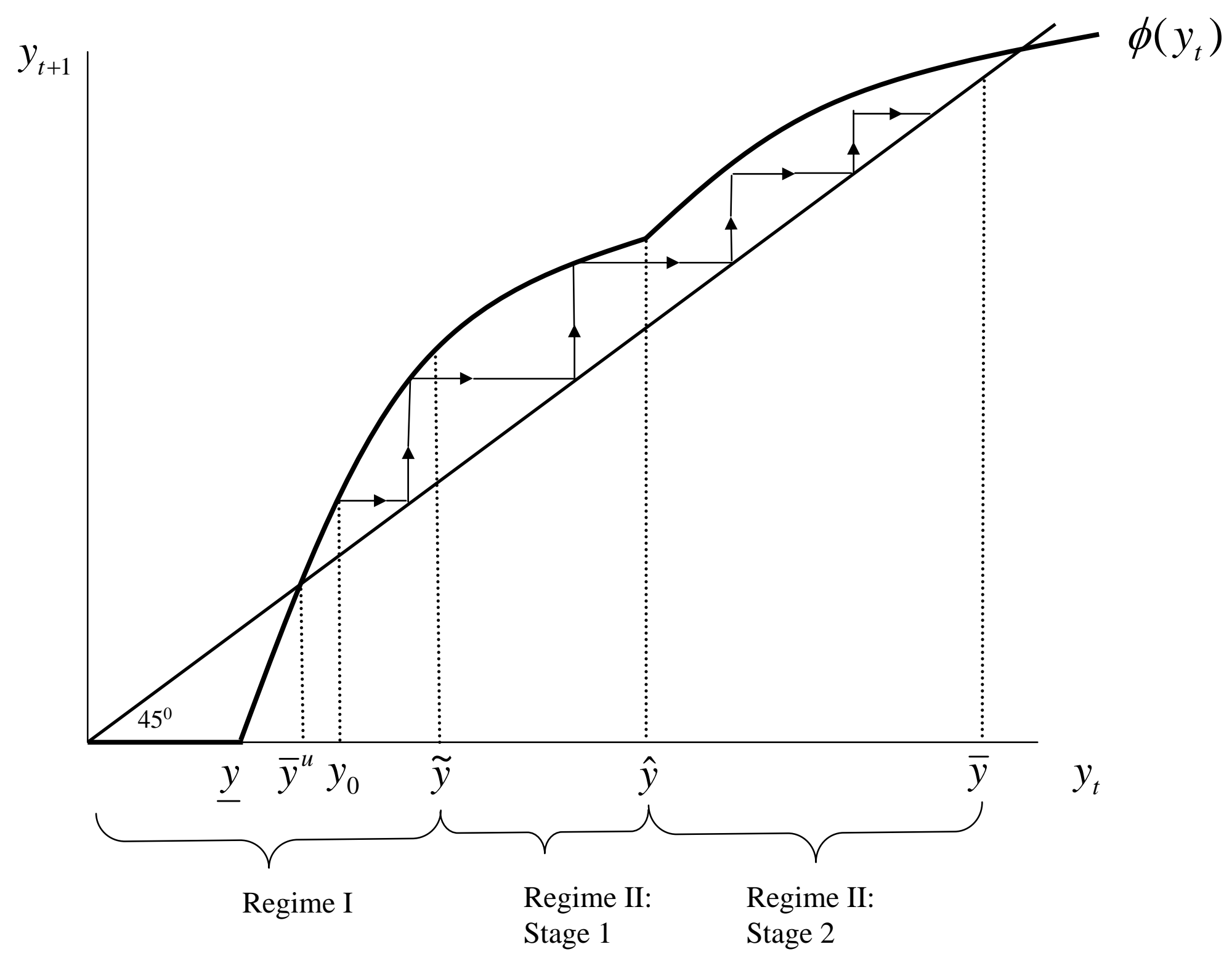

